\title{
WATER-RESOURCES ACTIVITIES, NORTH DAKOTA DISTRICT, \\ FISCAL YEAR 1992
}

Compiled by Cathy R. Martin

\section{U.S. GEOLOGICAL SURVEY}

Open-File Report 93-52 


\section{U.S. DEPARTMENT OF THE INTERIOR \\ BRUCE BABBIT, Secretary \\ U.S. GEOLOGICAL SURVEY \\ Dallas L. Peck, Director}

For additional information write to:

District Chief

U.S. Geological Survey

Water Resources Division

821 East Interstate Avenue

Bismarck, ND 58501
Copies of this report can be purchased from:

U.S. Geological Survey Books and Open-File Reports Federal Center

Box 25425

Denver, CO 80225 


\section{FOREWARD}

The North Dakota District of the U.S. Geological Survey, Water Resources Division, collects water-resources data and conducts interpretative investigations in cooperation with many State, local, and other Federal agencies. The District operates extensive data-collection networks that provide the types of information on surface-water and ground-water quantity and quality that are needed on a continuing basis by those who are responsible for managing the State's water resources. The District also conducts interpretative projects that are relevant to contemporary water issues or problems in North Dakota.

Since publication of the previous edition of this report, North Dakota has experienced 2 more years of drought. Statewide, 1992 was a better year for agriculture than the previous several years because of timely summer rains and generally cool summer temperatures. Hydrologic conditions, however, still are indicative of drought, particularly in the central and western parts of the State where streamflow in most streams during 1992 was much below normal. Sustained low water levels in Lake Sakakawea and continued declining levels in Devils Lake have been an increasing concern the past years. To help address questions about the waterquality impacts of the low pool elevation in Lake Sakakawea, the District, in cooperation with the U.S. Army Corps of Engineers, the North Dakota State Department of Health and Consolidated Laboratories, and the Three Affiliated Tribes, began a program in 1992 to monitor the water quality at several locations and depths in the lake.

As State and Federal agencies advance plans to stabilize the level of Devils Lake with Missouri River water, understanding of historic and current hydrologic and water-quality conditions in Devils Lake is essential. The District has continued to monitor seasonal and annual variations in the water quality of Devils Lake and the climatic factors that affect the evaporation and, therefore, the water level in the lake. Recent studies have (1) examined the importance of contributions of chemical constituents from the bottom sediments to the water quality of the lake and (2) used sediment cores to interpret the chronology of mercury accumulation in the lake. The monitoring programs and several interpretative studies the District has conducted during the past decade in cooperation with many State and Federal agencies provide the types of information that will be needed to project the water-quality effects of using Missouri River water to stabilize the level of Devils Lake.

In some parts of the country, studies show that pesticides commonly are found in surface water and ground water in concentrations that exceed State and Federal water-quality standards. The District's water-quality monitoring and interpretative studies programs in North Dakota include sampling for analyses of pesticides at several gaging-station locations and from selected ground-water wells. Results to date indicate that pesticides are detected less commonly in streams and ground water in North Dakota than in some of the midwestern cornbelt states, but the fact that detections do occur points to the need for continued monitoring to provide information useful for the development of programs to lessen impacts of nonpoint-source contamination of water resources. 
In 1993, we are hopeful of an end to the drought that North Dakotan's have experienced for the past 5 years. I would like to note in the next edition of this report that streamflows across the State for 1993-94 have been normal or somewhat above normal, that lake and reservoir levels have fully recovered, and that water-quality conditions across the State are excellent. The U.S. Geological Survey and its cooperators will strive, during these times of increasing austerity at all levels of government, to maintain programs that adequately characterize the quantity, quality, and use of North Dakota's water resources and help provide high quality scientific information that is needed by water-management agencies and the public to deal with important current water issues.

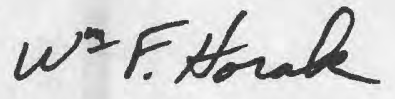

Wm. F. Horak

District Chief 


\section{CONTENTS}

Introduction -._____-_- 1

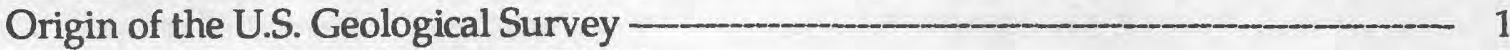

Mission of the Water Resources Division_______________________ 3

Sources of information and Water Resources Division publications - _ _ 4

National Water Data Exchange (NAWDEX) program-_____________ 4

National Water Information System (NWIS) ___ _ _ _ _ _ _ 4

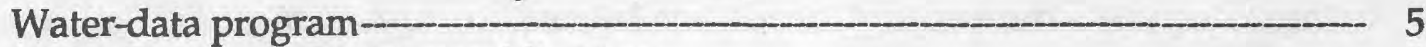

Water Resources Division publications-__________- 5

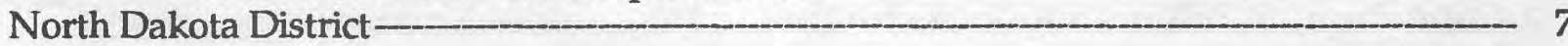

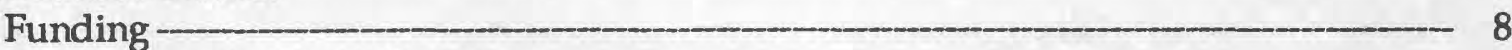

Water issues in North Dakota ___ _ _ _ _ 9

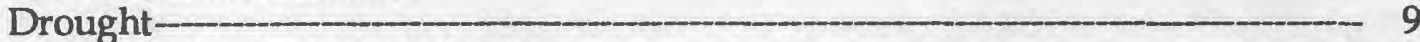

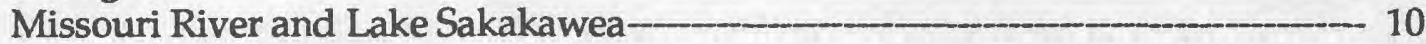

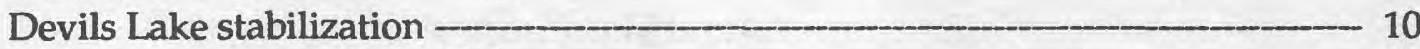

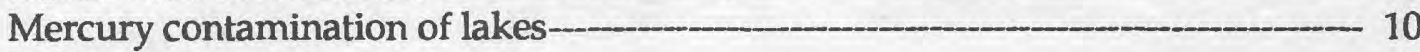

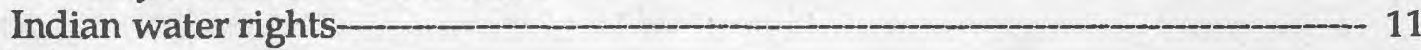

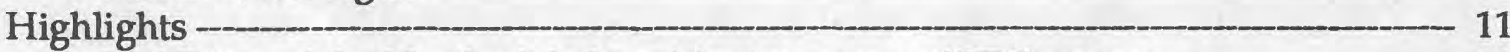

Red River of the North global positioning system (GPS) survey-_-______ 11

Water-quality monitoring on Lake Sakakawea___________________ 11

Hydrologic and human aspects of the 1988-92 drought in North Dakota

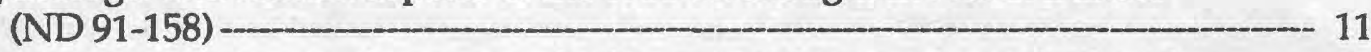

Mechanisms that control seepage of saline ground water through glacial confining units beneath the Red River of the North and its tributaries (ND 91-162)

Chronology of mercury loading to Devils Lake, North Dakota, inferred from sediment core data (ND 92-164) ___ 14

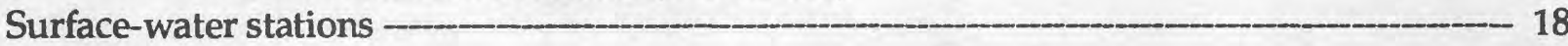

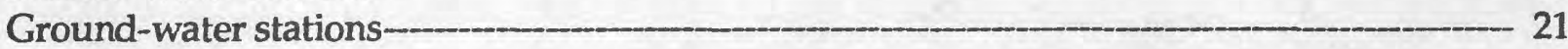

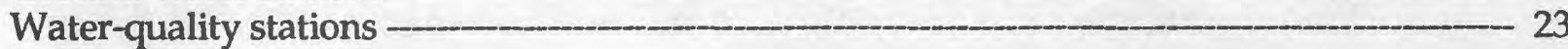

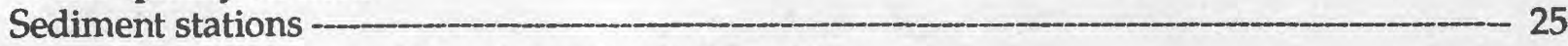

National trends network for atmospheric deposition _________________ 26

Water-use data acquisition and dissemination program__________________ 27

Boards and commissions-__-_-__-_ 29

Evaporation and ground-water interaction of Devils Lake, North Dakota-________ 30

Relation between upper-air flow patterns, climate, and hydrologic variability in the

Red River of the North basin, North Dakota, South Dakota, Minnesota, Manitoba,

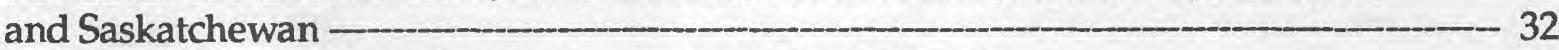

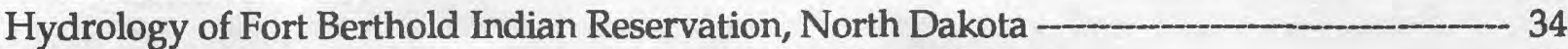

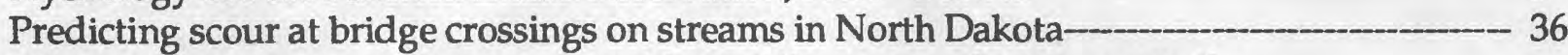

Effects of evapotranspiration on pesticide distributions and transport in the

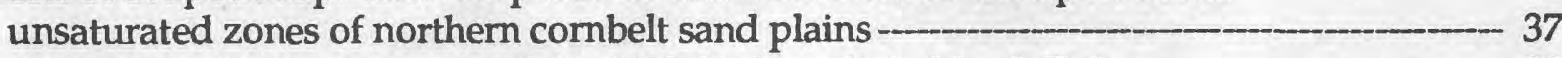

Hydrologic and human aspects of the 1988-92 drought in North Dakota_-_________- 38

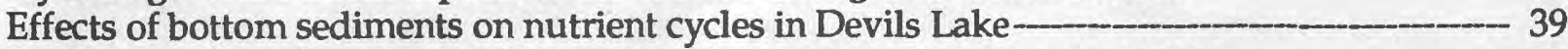

Evaluation of hydrocarbon and capillary fringe thickness and potential for contaminant movement in the upper aquifer system in the vicinity of the Flying J

Facility, Williston, North Dakota- 


\section{CONTENTS, Continued}

Page

Mechanisms that control seepage of saline ground water through glacial confining units beneath the Red River of the North and its tributaries

National water-quality assessment, Red River of the North basin 43

Chronology of mercury loading to Devils Lake, North Dakota, inferred from sediment core data-

Hydrology of the Fort Totten Indian Reservation, North Dakota

Development and application of geographic information system (GIS) data bases for North Dakota

Data development and analysis for use in Garrison Diversion Unit monthly operations model on the James River

Other activities of the North Dakota District

Supplement 1. Reports approved from October 1, 1990, through September 30, 1992

\section{ILLUSTRATIONS}

Figure 1. Diagram showing North Dakota District organizational structure-

2. Pie diagram showing percentage of funding from principal sources for fiscal year 1992

3. Map showing locations of lake, crest-stage, and stream-gaging stations in 1992

4. Map showing locations of ground-water observation wells in basic network in 1992

5. Map showing locations of surface-water stations where water-quality data were collected in 1992

\section{TABLES}

Table 1. North Dakota District offices-

2. Agencies cooperating in water-resources investigations in fiscal year 1992

3. Station-classification summary for 1992 


\section{WATER-RESOURCES ACTIVITIES, \\ NORTH DAKOTA DISTRICT, \\ FISCAL YEAR 1992}

Compiled by Cathy R. Martin

\section{INTRODUCTION}

The mission of the U.S. Geological Survey, Water Resources Division, is to provide the hydrologic information and understanding needed for the optimum utilization and management of the Nation's water resources for the overall benefit of the people of the United States. This report describes water-resources activities of the Water Resources Division in North Dakota in fiscal year 1992. Information on each project includes objectives, approach, progress, plans for fiscal year 1993, and completed and planned report products.

\section{Oriain of the U.S. Geological Survey}

The U.S. Geological Survey was established by an act of Congress on March 3, 1879, to provide a permanent Federal agency to conduct the systematic and scientific classification of the public lands and examination of the geological structure, mineral resources, and products of national domain. An integral part of that original mission includes publishing and disseminating the earth-science information needed to understand, to plan the use of, and to manage the Nation's energy, land, mineral, and water resources.

Since 1879, the research and factfinding role of the U.S. Geological Survey has grown and been modified to meet the changing needs of the Nation. As part of that evolution, the U.S. Geological Survey has become the Federal Government's largest earth-science research agency, the Nation's largest civilian mapmaking agency, the primary source of data on the Nation's surface- and ground-water resources, and the employer of the largest number of professional earth scientists. Today's programs are designed to meet the needs of a diverse group of users. Programs include: sciences;

--Conducting and sponsoring research in geology, hydrology, mapping, and related

--Producing and updating geographic, cartographic, and remotely sensed information in graphic and digital forms;

--Describing the onshore and offshore geologic framework and developing an understanding of its formation and evolution;

--Assessing energy and mineral resources, determining their origin and manner of occurrence, and developing techniques for their discovery;

--Collecting and analyzing data on the quantity and quality of surface water and ground water, on water use, and on quality of precipitation;

--Assessing water resources and developing an understanding of the impact of human activities and natural phenomena on hydrologic systems;

--Evaluating hazards associated with earthquakes, volcanoes, floods, droughts, toxic materials, landslides, subsidence, and other ground failures, and developing methods for hazards prediction;

--Publishing reports and maps, establishing and maintaining earth-science data bases, and disseminating earth-science data and information; 


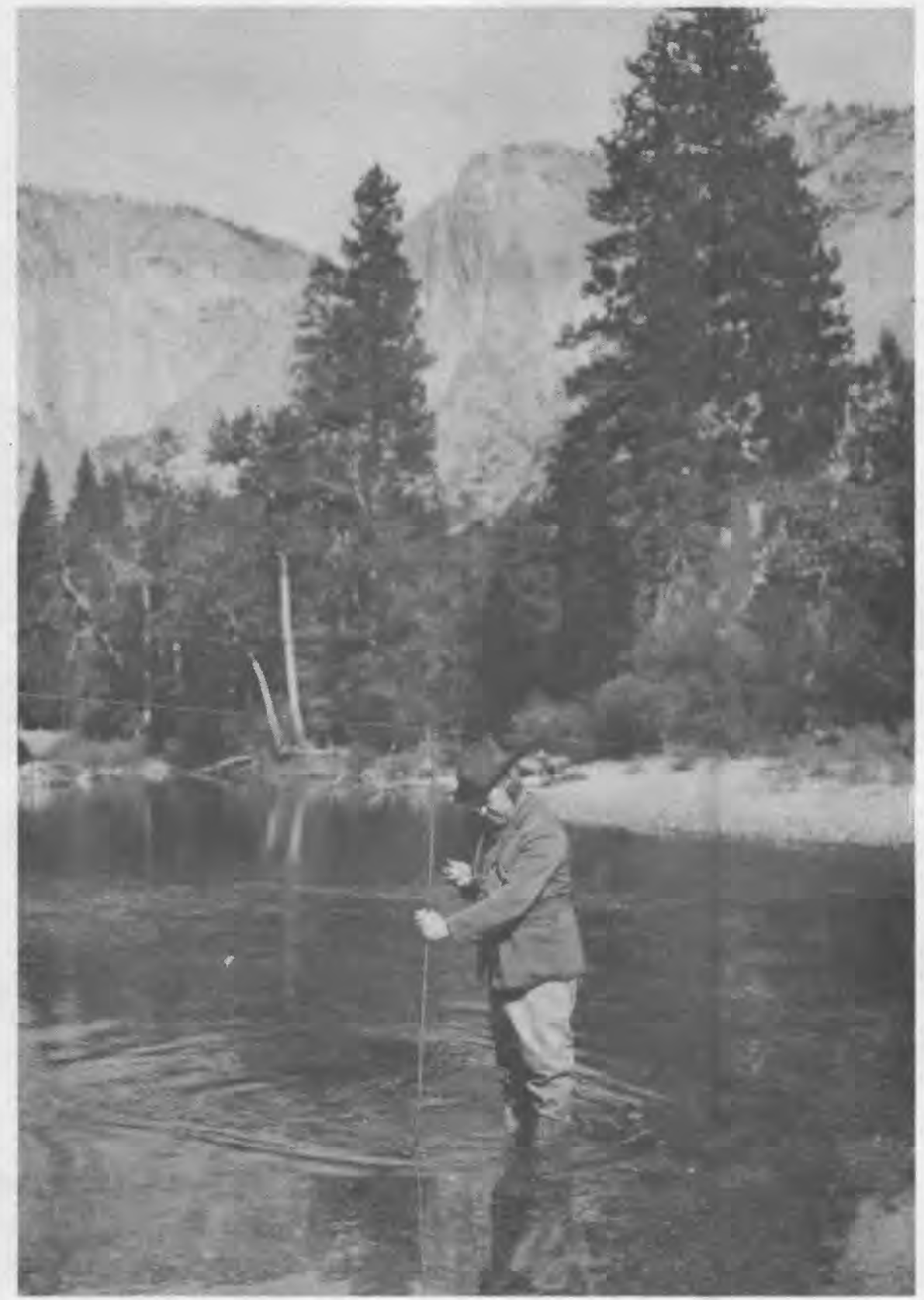

WADING MEASUREMENT, LATE 1800'S (Water-Supply Paper 43)

-Providing scientific and technical assistance for the effective use of earth-science techniques, products, and information;

--Coordinating topographic, geologic, and land-use mapping, digital cartography, and water-data activities; 


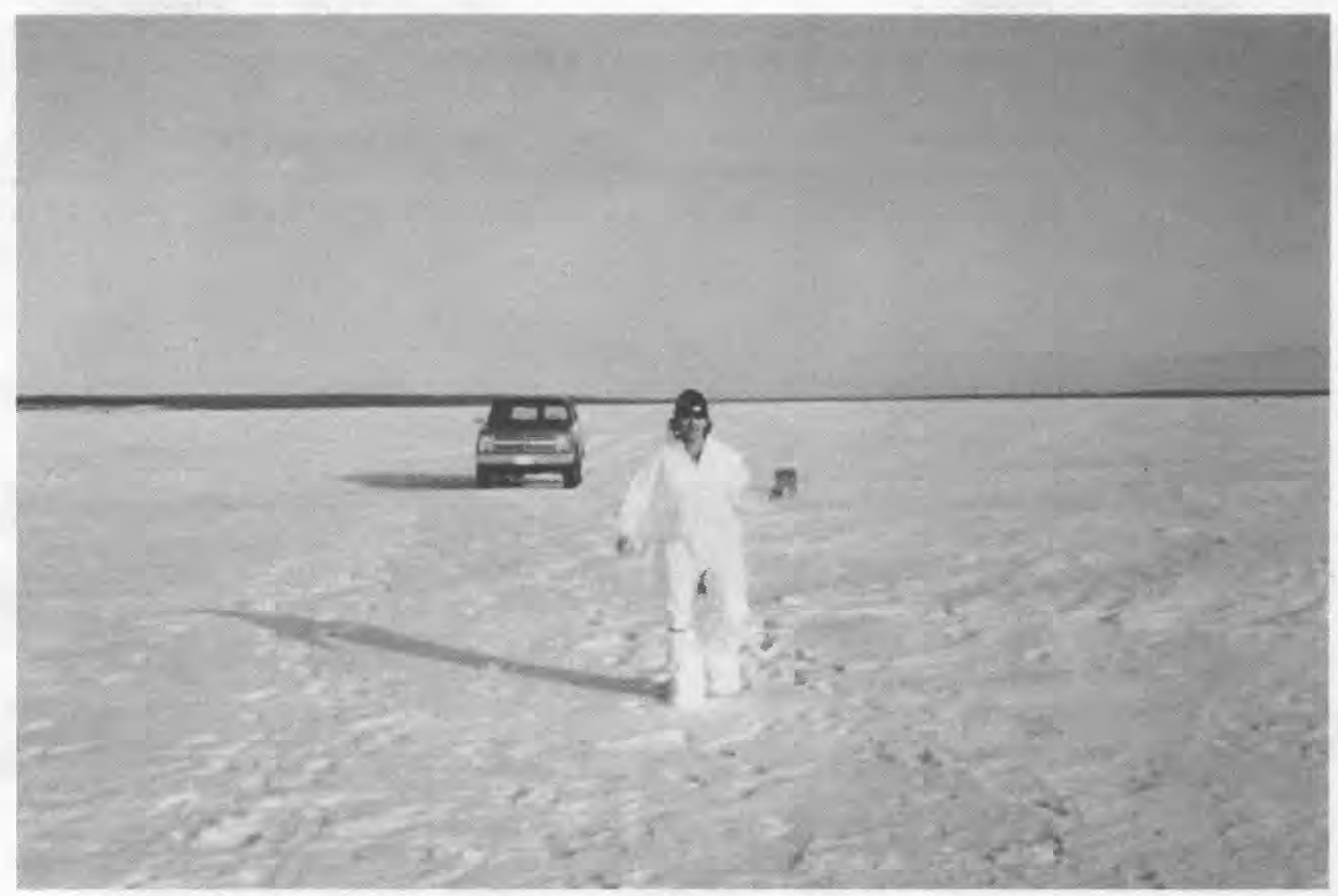

\section{ULTRACLEAN TRACE-ELEMENT SAMPLING IN EAST DEVILS LAKE, NORTH DAKOTA}

--Developing new technologies for the collection, coordination, and interpretation of earthscience data.

Along with its continuing commitment to meet the growing and changing earth-science needs of the Nation, the U.S. Geological Survey remains dedicated to its original mission to collect, analyze, interpret, publish, and disseminate information about the natural resources of the Nation--providing earth science in the public service.

\section{Mission of the Water Resources Division}

The mission of the Water Resources Division is to provide the hydrologic information and understanding needed for the optimum utilization and management of the Nation's water resources for the overall benefit of the people of the United States. This is accomplished, in large part, through cooperation with other Federal and non-Federal agencies by:

--Collecting, on a systematic basis, data needed for the continuing determination and evaluation of the quantity, quality, and use of the Nation's water resources; 
-Conducting analytical and interpretative water-resources appraisals describing the occurrence, the availability, and the physical, chemical, and biological characteristics of surface and ground water;

-Conducting supportive basic and problem-oriented research in hydraulics, hydrology, and related fields of science to improve the scientific basis for investigations and measurement techniques and to understand hydrologic systems sufficiently well to quantitatively predict their response to stress, either natural or manmade;

--Disseminating water data and results of investigations and research through reports, maps, computerized information services, and other forms of public releases;

--Coordinating activities of Federal agencies in the acquisition of water data for streams, lakes, reservoirs, estuaries, and ground waters;

-Providing scientific and technical assistance in hydrologic fields to other Federal, State, and local agencies, to licensees of the Federal Power Commission, and to international agencies on behalf of the Department of State.

\section{Sources of Information and Water Resources Division Publications}

The U.S. Geological Survey disseminates earth-science information through a network of public access points and an extensive publications program. Information on U.S: Geological Survey programs may be obtained from the Public Inquiries Office, U.S. Geological Survey, 169 Federal Building, 1961 Stout Street, Denver, CO 80294, or from U.S. Geological Survey Circular 900, "Guide to Obtaining USGS Information."

\section{National Water Daia Exchange (NAWDEX) Program}

The Water Data Source Directory (WDSD) is a computerized data base developed and maintained by the National Water Data Exchange (NAWDEX) Program Office. The directory contains information about organizations that collect, store, and disseminate water data. This information includes the type of each organization; the major orientation of water-data activities conducted by each organization; the names, addresses, and telephone numbers of offices within each organization from which water data may be obtained; the types of data available from each organization and the geographic locations where these data have been collected; and alternate sources of an organization's data.

\section{National Water Information System (NWIS)}

The national Water Data Storage and Retrieval (WATSTORE) system was a large-scale computerized storage and retrieval system used by the U.S. Geological Survey to store and disseminate water data. The WATSTORE system had data-processing, storage, and retrieval capabilities as well as the capability of providing computer-printed tables and graphs, statistical analyses of data, and digital plots.

The WATSTORE system, which basically had remained unchanged for about 10 years, gradually has been replaced by a new water-data management system. The new system is called the National Water Information System (NWIS). A fundamental change from the WATSTORE system to the NWIS was the distribution of water data from a central computer in Reston, Va., to minicomputers at district offices throughout the Nation. The Reston computer remains as an archival data repository. Data-management software has been enhanced to streamline data processing, allow for direct entry of data relayed through satellite, and permit processing of variable-interval data in addition to fixed-interval data. Data management has become easier, 
and data can be processed more quickly than before. Improvements in timeliness of data a vailability have occurred and further improvements are expected as software is developed for the new system.

All surface-water streamflow and stage data available for North Dakota were downloaded to the North Dakota District minicomputer during 1984. Beginning with the 1984 water year, all data processing for surface-water data has been done on the District minicomputer. The Automatic Data Processing System (ADAPS), a series of computer data-processing programs making up a segment of the NWIS, was installed on the North Dakota District minicomputer in August 1987. Surface-water data collected during the 1987 water year were prepared for publication using the ADAPS software.

In May 1985, all ground-water site information and water levels were downloaded from the Reston computer. All water-quality data also have been downloaded to the District minicomputer. This downloading completed the distribution of data processing from the central computer in Reston, Va., to the districts.

\section{Water-Data Program}

Water-data stations at selected locations throughout the Nation are used by the U.S. Geological Survey to obtain records of stream discharge (flow) and stage (height), reservoir and lake storage, ground-water levels, well and spring discharge, and the quality of surface and ground water. These data provide a continuing record of the quantity and quality of the Nation's surface- and ground-water resources and, thus, provide the hydrologic information needed by Federal, State, and local agencies and the private sector for the development and management of land and water resources. All data collected are stored in the NWIS and also are published, by water year, for each state in a publication series entitled "U.S. Geological Survey Water-Resources Data Reports" (see section "Water Resources Division Publications" for availability of these reports). Information about the water-data program can be obtained from the Assistant Chief Hydrologist for Operations at the headquarters office in Reston, Va., or from the District Chief of the state of interest.

\section{Water Resources Division Publications}

Information on a wide variety of earth-science specialties is published in many forms, including the Federal book series and the map series. Book publications include a formal series of water-supply papers, professional papers, bulletins, circulars, techniques of water-resources investigations, and special reports and an informal series of water-resources investigations reports, open-file reports, and administrative reports. Map publications include a formal series of hydrologic investigations atlases and miscellaneous investigations maps and an informal series of water-resources investigations reports, open-file reports, and miscellaneous field studies maps. New reports are announced monthly in "New Publications of the Geological Survey," subscriptions to which are available upon request from the U.S. Geological Survey, 582 National Center, Reston, VA 22092.

Formal series book publications are sold by the U.S. Geological Survey, Books and OpenFile Reports, Federal Center, Box 25425, Denver, CO 80225; single copies of circulars still in print are available upon request from that address. Map publications pertaining to North Dakota are sold by the U.S. Geological Survey, Western Distribution Branch, Box 25286, Federal Center, Denver, CO 80225. 
Water-resources investigations reports and open-file reports pertaining to North Dakota are available for inspection at the U.S. Geological Survey, Water Resources Division, 821 East Interstate Avenue, Bismarck, ND 58501; information on their availability also may be obtained from the District Chief at that address. In addition, those reports having an alphanumeric designation in parentheses at the end of the citation may be purchased as paper copy or microfiche from the U.S. Geological Survey, Books and Open-File Reports, Federal Center, Box 25425, Denver, CO 80225-the alphanumeric designation is required when ordering from Books and Open-File Reports.

The series of reports entitled "Water-Resources Data for (State) for (Year)," describing surface water, ground water, and water quality in each state, may be purchased from the National Technical Information Service, U.S. Department of Commerce, 5285 Port Royal Road, Springfield, VA 22161. The reports can be inspected in U.S. Geological Survey libraries and in Water Resources Division district offices in the region of the report.

6 


\section{NORTH DAKOTA DISTRICT}

The North Dakota District is 1 of 43 districts of the U.S. Geological Survey, Water Resources Division. The District boundaries are coincident with those of the State, and offices are located in Bismarck and Grand Forks (table 1). District organization is shown in figure 1.

Table 1: North Dakota District offices

\begin{tabular}{l|ll}
\hline \multicolumn{1}{c|}{ Office } & Telephone number & \multicolumn{1}{c}{ Address } \\
\hline District office & $(701)$ 250-4601 & U.S. Geological Survey \\
& & $\begin{array}{l}\text { Water Resources Division } \\
\text { 821 East Interstate Avenue }\end{array}$ \\
& & Bismarck, ND 58501 \\
Grand Forks field headquarters & $(701)$ 775-7221 & U.S. Geological Survey \\
& & Water Resources Division \\
& & P.O. Box 1437 \\
& & Grand Forks, ND 58206-1437 \\
\hline
\end{tabular}

\section{NORTH DAKOTA DISTRICT ORGANIZATION Wm. F. Horak, District Chief}

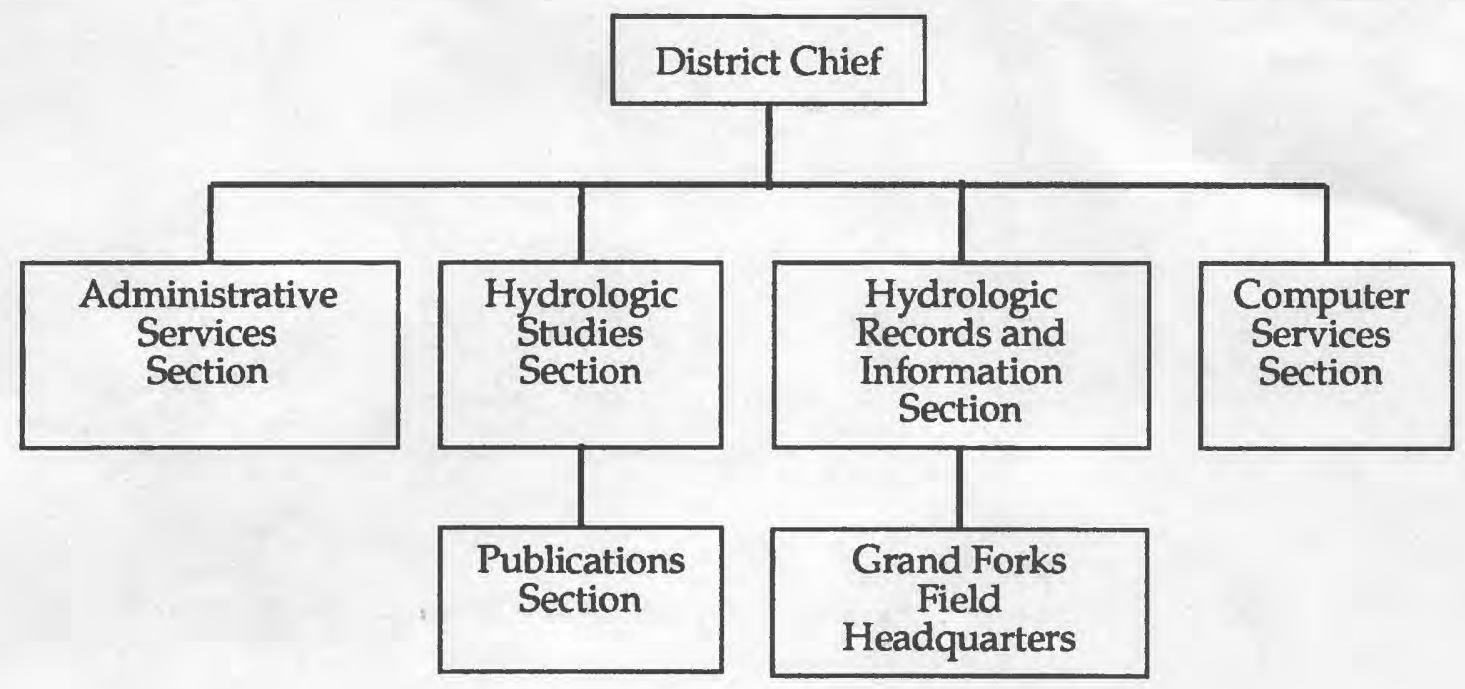

Figure 1.-North Dakota District organizational structure. 


\section{Funding}

Funds to support water-resources activities of the North Dakota District are derived from three principal sources:

(1) Federal program-Funds are appropriated by Congress for support of prescribed activities. In fiscal year 1992, Federal funding for North Dakota District program activities was $\$ 597,184$.

(2) Federal-State Cooperative program--Federal funds are appropriated by Congress and used to match those furnished by State and other tax-supported agencies. These funds are used for a variety of hydrologic data-collection activities and water-resources investigations in which the U.S. Geological Survey represents the national interest and the cooperating agencies represent State and local interests. In fiscal year 1992, Federal-State Cooperative funding for the North Dakota District was $\$ 1,490,826$.

(3) Other Federal Agencies (OFA) program-Funds are transferred to the U.S. Geological Survey as reimbursement for work conducted at the request of other Federal agencies. In fiscal year 1992, OFA funding was $\$ 894,026$.

The total budget for fiscal year 1992 was $\$ 2,982,036$. The percentage of funding from each principal source is shown in figure 2. Agencies cooperating in water-resources investigations in fiscal year 1992 are given in table 2.
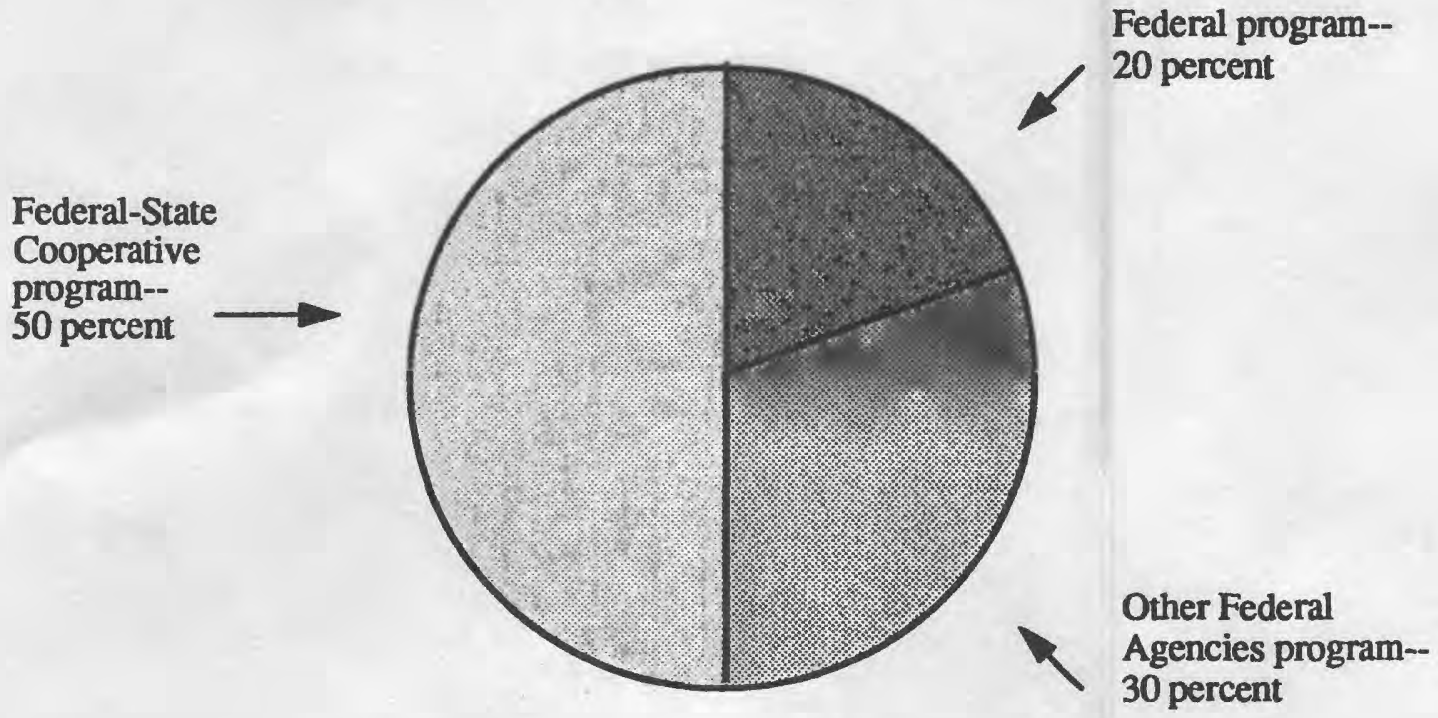

Figure 2.-Percentage of funding from principal sources for fiscal year 1992.

The types of activities conducted by the North Dakota District include research projects, areal appraisals and interpretative studies, and collection of hydrologic data. The relative District involvement in each of these activities, in terms of funding, is about 5 percent for research projects, about 32 percent for areal appraisals and interpretative studies, and about 62 percent for collection of hydrologic data. 
Table 2: Agencies cooperating in water-resources investigations in fiscal year 1992

Federal agencies

U.S. Department of the Army
Corps of Engineers
Omaha District
St. Paul District
U.S. Department of the Interior
Bureau of Indian Affairs
Bureau of Reclamation
Fish and Wildlife Service
U.S. Department of State
International Joint Commission
Waterways Treaty Program
U.S. Environmental Protection Agency

State agencies

North Dakota Department of Transportation

North Dakota Game and Fish Department

North Dakota Geological Survey

North Dakota Parks and Recreation Board

North Dakota State Department of Health and Consolidated Laboratories

North Dakota State Water Commission

Local agencies

\section{City of Dickinson}

City of Minot

Devils Lake Sioux Tribe

Lower Heart River Water Resource District

Three Affiliated Tribes

\section{Water Issues in North Dakota}

Many water issues received attention in North Dakota during the past 12 months. Some of those issues are highlighted in the following paragraphs.

\section{Drought}

Last year (1992) was the fifth consecutive year of drought in North Dakota although summer rains in east-central North Dakota brought some relief from the drought. Generally, precipitation was deficient for January through August, except in the northeast part of the State. Crops fared better than might have normally been the case because the June-August temperature was the second coolest in about 100 years of record and because of timely summer rains.

Statewide precipitation was near normal for part of the summer, but, after 4 years of severe drought, normal precipitation was not enough to recharge soil moisture and produce normal runoff. As an example, the mean daily discharge for the Knife River at Hazen during 1992 was 
14 percent of the mean daily discharge for 1929-92. Statewide streamflow was less than the mean at most gaging stations.

In cooperation with the North Dakota State Water Commission, the U.S. Geological Survey began a study in 1991 to document the hydrologic effects of the drought. The climatic conditions and the hydrologic response associated with the drought will be summarized in a report.

\section{Missouri River and Lake Sakakawea}

Unprecedented declines in water levels of Missouri River main-stem reservoirs have resulted from the severe drought that began in 1988. In May 1991, the pool elevation of Lake Sakakawea reached its lowest level $(1,815$ feet) since the reservoir was originally filled in the 1960 's. In July 1991, the pool elevation rose to about 1,829 feet, the highest level recorded that year. The level generally declined in early 1992, then peaked at about 1,825 feet in July 1992. On December 31, 1992, the pool elevation was about 1,819 feet. Normal pool operating level is about 1,850 feet.

The low water levels have rendered some water-supply intakes inoperable and hindered recreational access. Public concern about the current operating plan for the six large dams and reservoirs on the Missouri River prompted the U.S. Army Corps of Engineers to begin a study in 1989 of numerous alternative operating plans and the economic, social, and environmental impacts of those plans. Public review of the alternative operating plans is scheduled for January 1993. The review will help identify the operating plan that best meets the wide variety of contemporary needs served by the Missouri River system.

\section{Devils Lake Stabilization}

Other than the Missouri River and Lake Sakakawea, Devils Lake is North Dakota's most important recreational and fish-producing water body. The continuing drought in North Dakota has markedly affected the lake. As of October 31, 1992, the water level of Devils Lake had declined nearly 6.4 feet since August 1987 when it reached a level of $1,428.8$ feet, the highest level since 1885. As the water level of Devils Lake declined, interest in alleviating rising water levels was replaced by interest in lake stabilization to protect water-based recreation and the fishery. Fish kills are forecast if the lake level declines below about 1,422 feet.

The State's favored plan for lake stabilization calls for the delivery of Missouri River water through existing canals of the Garrison Diversion Unit project and a proposed pipeline. The U.S. Army Corps of Engineers has completed a draft report of a reconnaissance study to determine the Federal interest and local funding support for a plan to divert Missouri River water into Devils Lake. If the stabilization project is advanced to the "feasibility" stage of study, several hydrologic and environmental issues will need to be addressed.

\section{Mercury Contamination of Lakes}

Analyses of fish-tissue samples collected during the spring and summer of 1991 in five North Dakota lakes by the North Dakota State Department of Health and Consolidated Laboratories have shown mercury concentrations in excess of fish consumption advisory levels. This was the first time in North Dakota that mercury levels that exceed the advisory levels were found in walleye and northern pike. Analyses of fish-tissue samples collected at several lakes since 1991 also have shown mercury concentrations in excess of advisory levels. The largest mercury concentrations in walleyes were from Devils Lake, the State's largest natural lake and 
one of its two most important walleye waters. A fish consumption advisory has been issued for the larger walleyes taken from Lake Sakakawea. The U.S. Geological Survey and the North Dakota State Department of Health and Consolidated Laboratories are conducting studies to monitor the occurrence of mercury in Devils Lake and to evaluate historic changes in the mercury input to the Devils Lake system.

\section{Indian Water Rights}

Indian reserved water rights are an important issue in North Dakota as well as throughout the arid western states. Some Indian tribes in those states have begun to consider water as a marketable commodity as well as an essential resource for development of industry, agriculture, and public water supplies on the reservations. Actual quantification of Indian water rights often involves settlement of contentious issues with State governments that otherwise have claim to the water. Nationally, determination of tribal Indian water rights is progressing both by negotiation and litigation. Regardless of the approach used, reliable hydrologic data are required to assess the water resources available on reservation lands. The U.S. Geological Survey is working with tribes in North Dakota, as well as throughout the nation, to gather data that may be used in the resolution of reserved rights and in developing tribal water-management plans.

\section{Highlights}

\section{Red River of the North Global Positioning System (GPS) Survey}

In early August 1991, the U.S. Army Corps of Engineers requested that the U.S. Geological Survey, North Dakota District, provide elevation data for more than 150 miles of highway crest, spoil banks, and railroad tracks as input for a flood model of the Red River of the North. The work could not be completed within the established timeframe if conventional means were used. Therefore, the surveying project for the U.S. Army Corps of Engineers was planned and completed using global positioning system (GPS) technology. Results were very encouraging and many new ideas for using this technology to enhance data collection for hydrologic studies have been suggested.

\section{Water-Quality Monitoring on Lake Sakakawea}

From July 1992 through October 1992, the U.S. Geological Survey collected monthly waterquality data from Lake Sakakawea. The monitoring was done in cooperation with the Three Affiliated Tribes, the North Dakota State Department of Health and Consolidated Laboratories, and the U.S. Army Corps of Engineers. Vertical profiles of $\mathrm{pH}$, specific-conductance, temperature, and dissolved oxygen were obtained at eight sites in the lake. Also, samples were taken from various depths at four of the eight sites for laboratory analyses of major ions, trace metals, and nutrients. The analyses were done in laboratories of the North Dakota State Department of Health and Consolidated Laboratories and the U.S. Army Corps of Engineers in Omaha, Nebr.

\section{Hydrologic and Human Aspects of the 1988-92 Drought in North Dakota (ND 91-158)}

North Dakota experienced one of its most severe droughts during 1988-92. Impacts on reservoir levels, streamflows, ground-water levels, water quality, and soil-moisture levels (or 


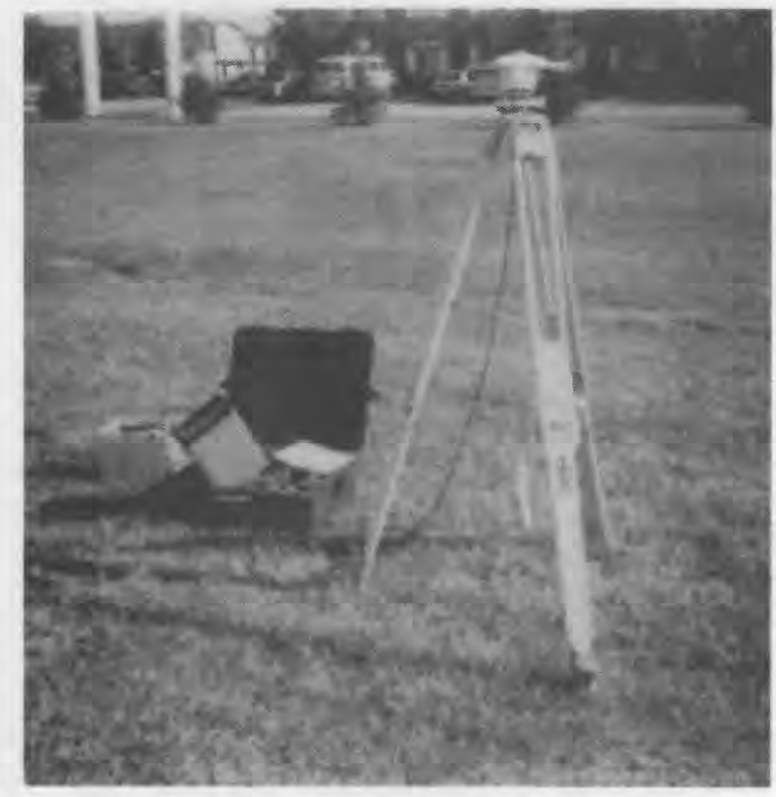

BATTERY, GLOBAL POSITIONING

SYSTEM RECEIVER, AND

TRIPOD-MOUNTED ANTENNA

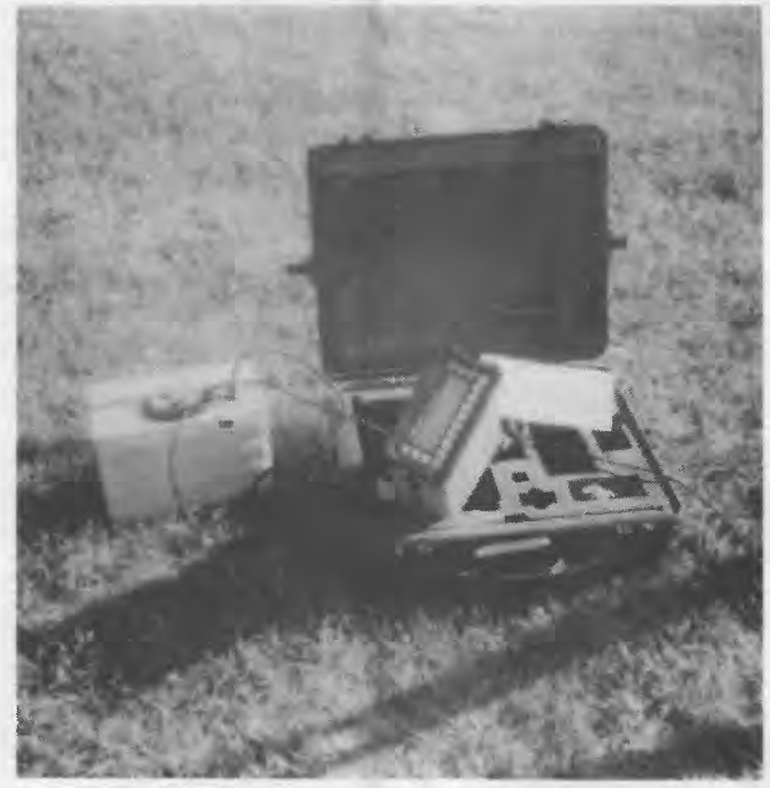

HIGH PRECISION GEODETIC-QUALITY

GLOBAL POSITIONING SYSTEM

RECEIVER CONNECTED TO BATTERY 


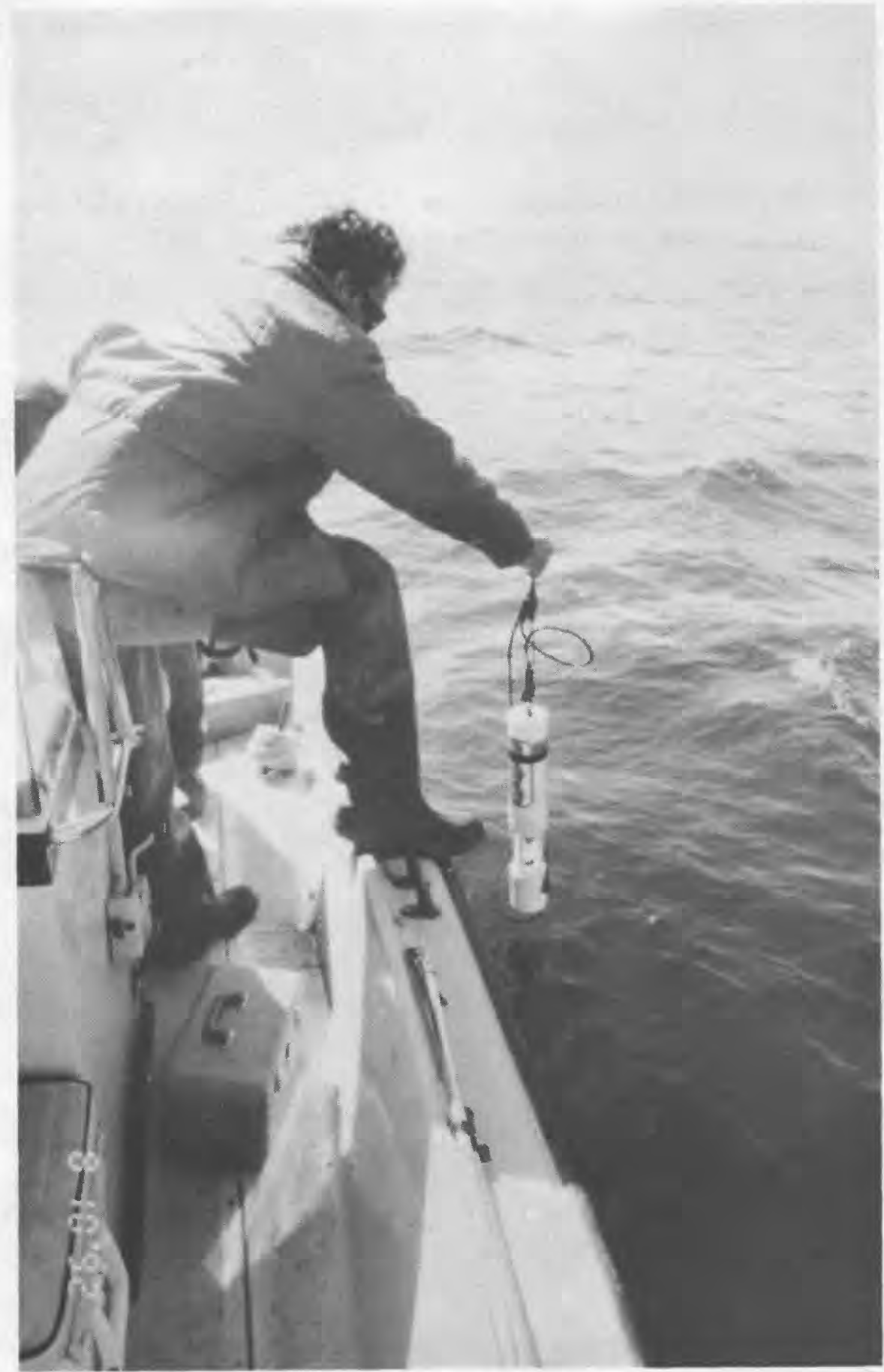

EQUIPMENT USED TO MEASURE $\mathrm{pH}$, SPECIFIC CONDUCTANCE, TEMPERATURE, AND DISSOLVED OXYGEN IN LAKE SAKAKAWEA 
North Dakota State Water Commission. The impacts of the drought on human activities also are being documented. In particular, the impacts on the following water uses will be described: public water supplies, rural water supplies, irrigation and agriculture, fisheries and wildlife, and recreation. The severity of the impacts will be determined by comparing the drought of 1988-92 to droughts of the 1930's, 1960's, and 1970's.

\section{Mechanisms that Control Seepage of Saline Ground Water Through Glacial Confining Units Beneath the Red River of the North and its Tributaries (ND 91-162)}

The problem of saline soils and elevated levels of dissolved solids in the Red River of the North and its tributaries caused by the discharge of saline ground water is being examined in this 3-year study. The study focuses on the geologic controls that limit the rate of ground-water flow through surficial deposits; however, anthropogenic influences on ground-water discharge, such as unrestricted flowing wells, also are examined. Water quality and hydrologic properties are evaluated for both surface-water and ground-water conditions, with special emphasis given to the examination of hydrologic connections between the two flow regimes. Three sets of nested wells were installed and used for measuring hydraulic conductivities and water chemistry at various levels in the surficial deposits. The information gained from the core analysis, evaluation of the hydraulic properties, and analysis of ground-water chemical evolution along flow paths was applied to a two-dimensional ground-water flow model to illustrate the complex flow and mixing of ground water in the surficial and bedrock units.

The contribution of flowing wells to the water quality of surface water in the region is presently being examined. It is estimated that thousands of flowing wells have been drilled over the past 100 years and, although most have either ceased to flow or have been plugged, many unrestricted flowing wells still exist in the study area. The inventory of these wells will help distinguish anthropogenic sources of salinity from natural seepage. This information, along with data collected from ground-water and surface-water studies and results of the twodimensional model, will be applied to a three-dimensional regional ground-water flow model. The three-dimensional model will provide a conceptual evaluation of hydrologic conditions existing in this part of the Red River of the North drainage basin.

\section{Chronology of Mercury Loading to Devils Lake, North Dakota, Inferred from Sediment Core Data (ND 92-164)}

Recreational fishing is a major tourist industry in the Devils Lake, N. Dak., area. In 1991, the North Dakota State Department of Health and Consolidated Laboratories reported that mercury concentrations in sport fish collected from Devils Lake were above background levels (as much as 1.84 micrograms per gram in large walleyes). These mercury concentrations may pose health risks to specific segments of the population. In response to these findings, the U.S. Geological Survey, in cooperation with the North Dakota State Department of Health and Consolidated Laboratories, began evaluating the distribution of mercury in Devils Lake.

In August 1991, sediment samples and invertebrate samples were collected for mercury analyses. In October 1991, water samples were collected from Main Bay, Sixmile Bay, Creel Bay, East Bay, East Devils Lake, West Stump Lake, and Sweetwater Lake for analyses of total and dissolved mercury. In February 1992, water samples were collected from several depths in Main Bay and East Devils Lake. All of the water samples were collected using ultraclean techniques to minimize sampling artifacts and to provide the best quality data possible. These data will be 


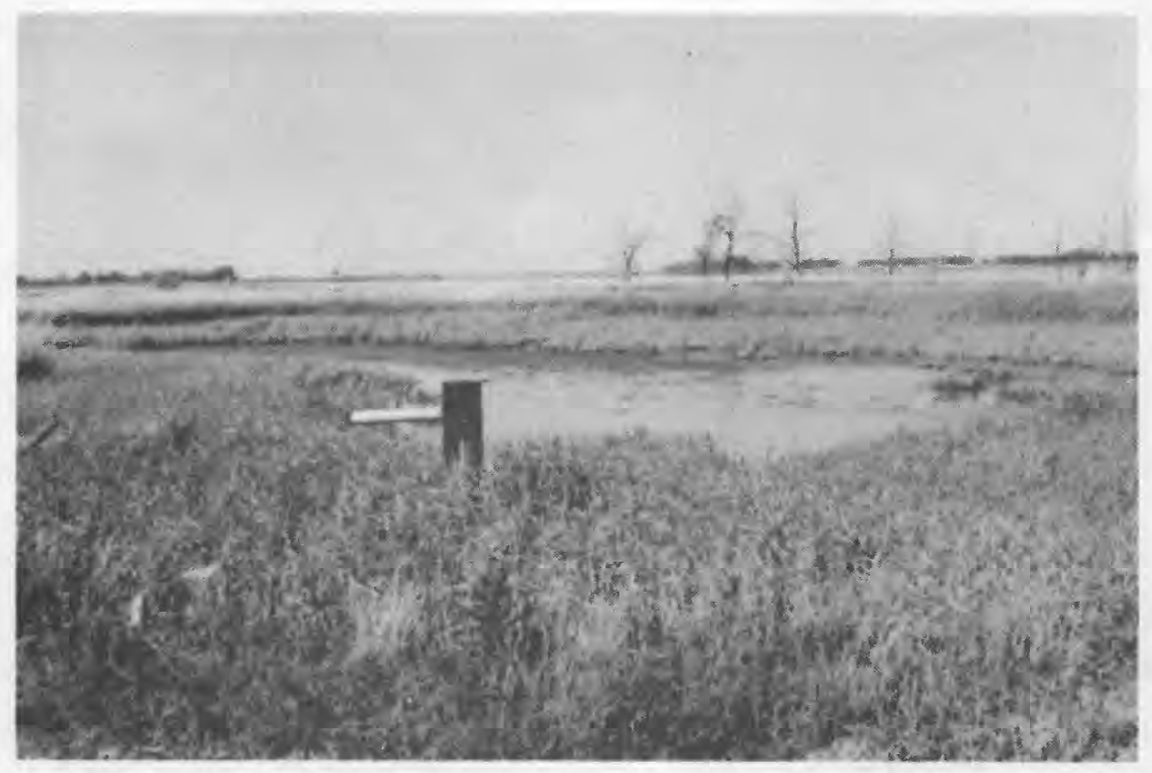

FLOWING WELL IN NORTHERN GRAND FORKS COUNTY, NORTH DAKOTA

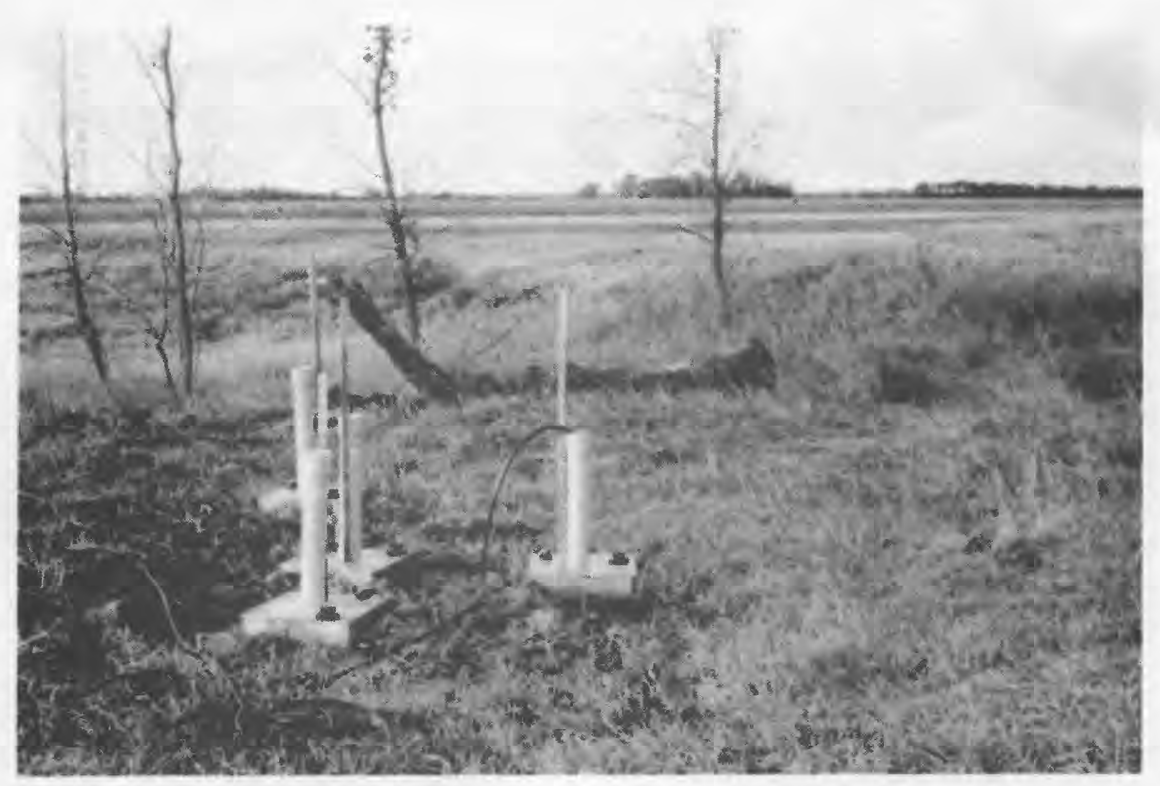

NEST OF OBSERVATION WELLS IN WALSH COUNTY, NORTH DAKOTA 


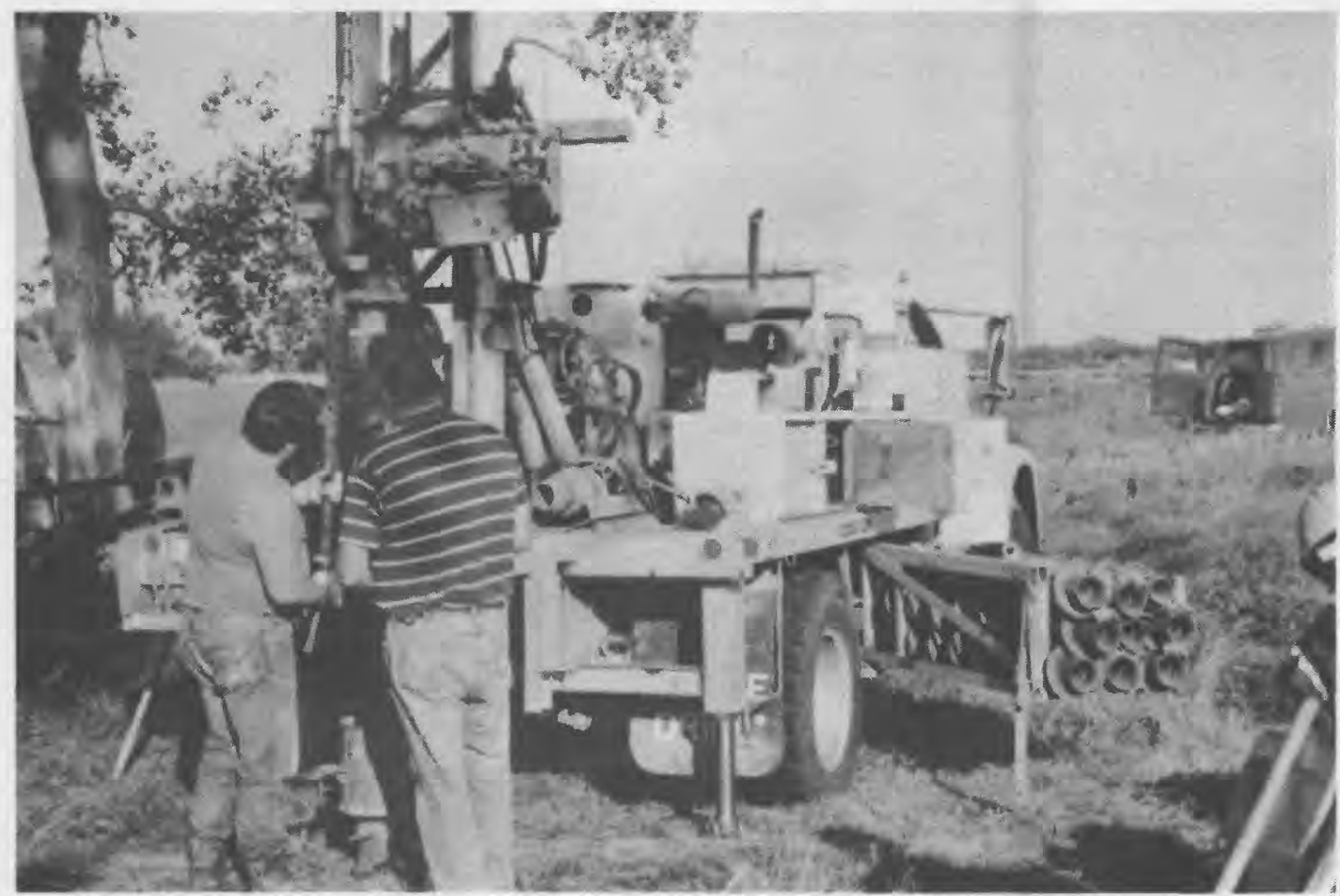

\section{AUGERING SURFICIAL DEPOSITS TO COLLECT CORES FOR TEXTURAL ANALYSIS AND TO INSTALL OBSERVATION WELLS}

used in conjunction with other water-quality and biologic data to compute the mercury mass in Devils Lake and to compare the mercury geochemistry of Devils Lake with other lakes in adjacent states.

In addition to the water-quality sampling, in January 1992, six sediment cores were collected from Main Bay, Creel Bay, East Bay, East Devils Lake, West Stump Lake, and Morrison Lake. The cores were analyzed for mercury, total organic carbon, and radioactive isotopes of cesium and lead. The purpose of the core analyses was to construct chronologies of mercury accumulation in the basin. The results will be used to clarify a number of issues, including preindustrial and modern levels of mercury input in Devils Lake, timing of increased mercury input to Devils Lake, and the total amount of mercury in the bottom sediments of Devils Lake. These data will be compared to similar data from other lakes in adjacent states to evaluate regional variations in mercury accumulation. 


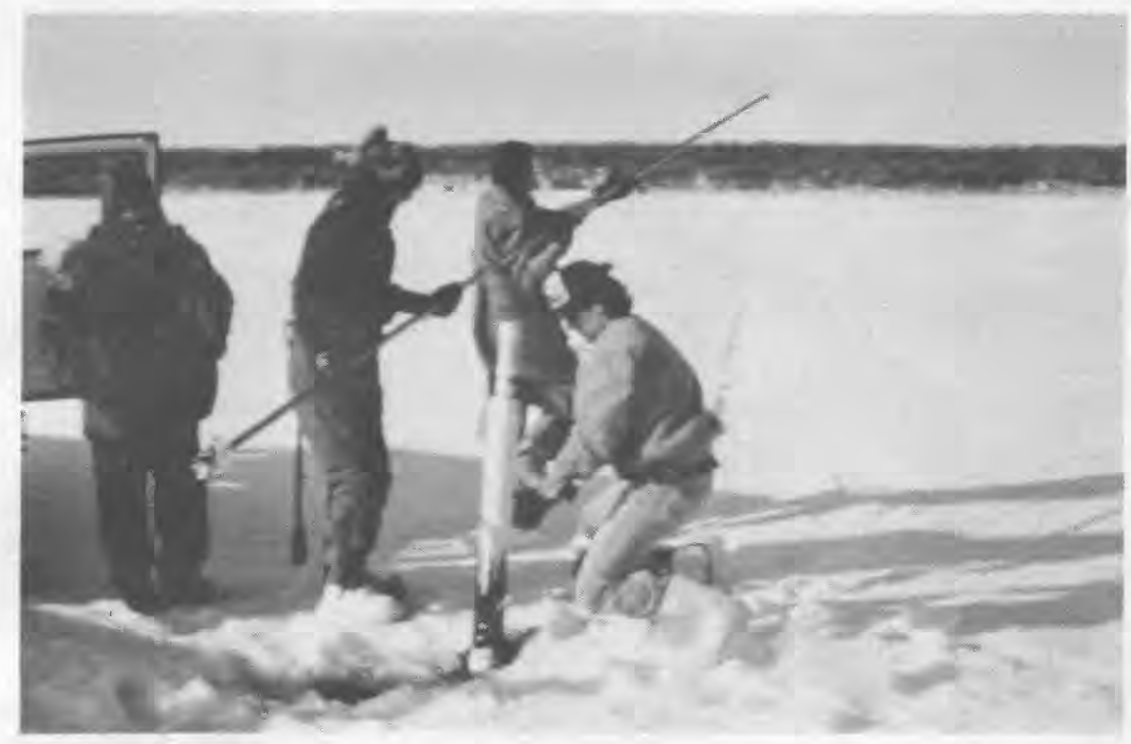

COLLECTING SEDIMENT CORES FOR MERCURY ANALYSIS, CREEL BAY, DEVILS LAKE, NORTH DAKOTA

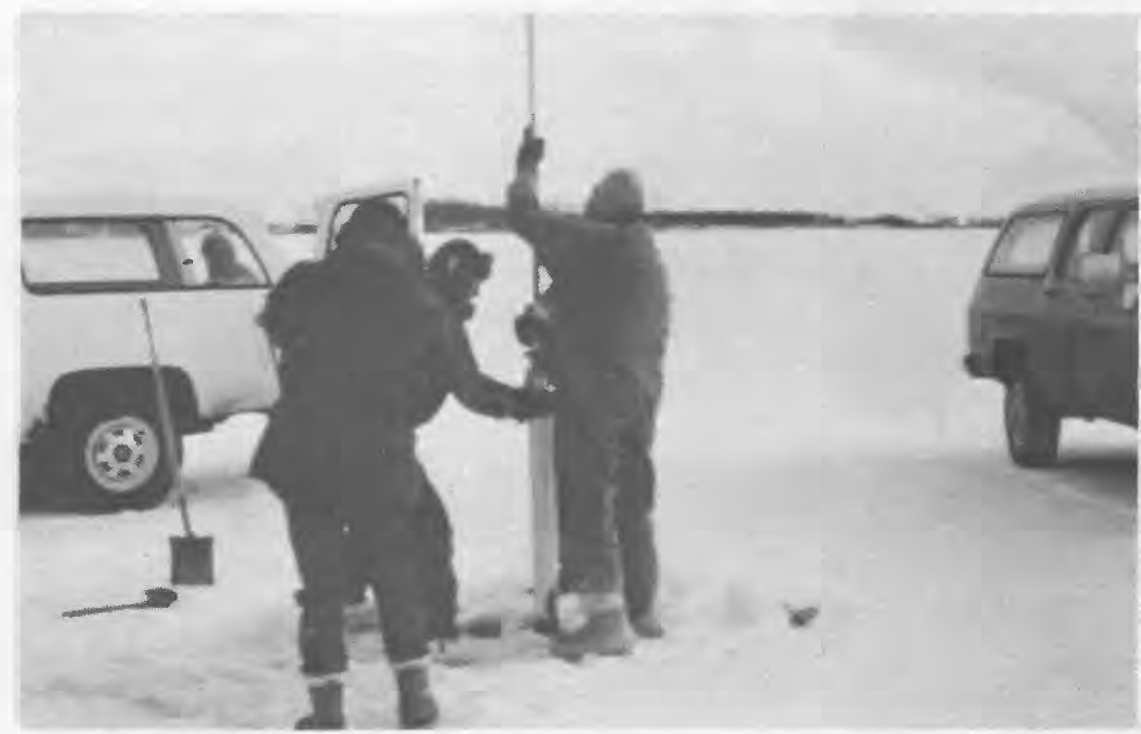

COLLECTING SEDIMENT CORES FOR MERCURY ANALYSIS, CREEL BAY, DEVILS LAKE, NORTH DAKOTA 


\section{SURFACE-WATER STATIONS}

PROJECT NUMBER: ND 00-001.

LOCATION: Statewide.

PERIOD OF PROJECT: Continuous.

PROJECT CHIEF: Russell E. Harkness.

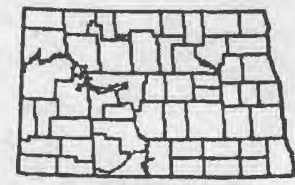

STATEWIDE

COOPERATING AGENCIES: (1) City of Dickinson; (2) Lower Heart River Water Resource District; (3) North Dakota Parks and Recreation Board; (4) North Dakota State Water Commission; (5) Three Affiliated Tribes; (6) U.S. Department of the Army, Corps of Engineers; (7) U.S. Department of the Interior, Bureau of Indian Affairs; (8) U.S. Department of the Interior, Bureau of Reclamation; (9) U.S. Department of the Interior, Fish and Wildlife Service; (10) U.S. Department of State, International Joint Commission, Waterways Treaty Program; and (11) other Federal agencies of the U.S. Department of the Interior for the development of the Missouri River basin.

PROBLEM: The operation of existing water projects and the planning of future work require the availability of accurate, unbiased streamflow and water-level data. The data must be available in a timely manner in order to assure efficient and effective operation of existing water projects. The data also must be available over a wide range of space and time in order to provide statistically accurate projections used for planning.

OBJECTIVES: Objectives are to (1) collect surface-water data needed for assessment of water resources, operation of reservoirs or industries, forecasting, disposal of wastes and pollution controls, compact and legal requirements, and research or special studies; (2) collect surface-water data needed to accompany water-quality measurements; and (3) collect surfacewater data needed for analytical studies at specific locations to define statistical distributions of, and trends in, the occurrence of water in streams, lakes, and reservoirs for use in planning and design.

APPROACH: Standard methods of data collection are used as described in the U.S. Geological Survey techniques of water-resources investigations report series. Partial-record gages are operated instead of complete-record gages where daily streamflow data are not required for the entire year. Discharge or stage data will be obtained for the stations shown in figure 3. A station-classification summary is given in table 3.

PROGRESS: All network data were collected on schedule, and records were prepared for publication. Two continuous-record streamflow stations and one continuous-record stage station were discontinued.

PLANS FOR FISCAL YEAR 1993: The streamflow-station network will be operated as scheduled. Cooperative work with State and Federal agencies to upgrade controls at streamflow stations will continue. Two streamflow stations will be installed and one stage station will be discontinued. An acoustic velocity meter will be installed at an active streamflow site to study practical use of acoustic velocity meters during winter ice cover.

\section{REPORT PRODUCTS:}

U.S. Geological Survey, 1992, Water-resources data, North Dakota, Water year 1991: U.S. Geological Survey Water-Data Report ND-91-1, 365 p.

U.S. Geological Survey, Water-resources data, North Dakota, Water year 1992 (in progress). 


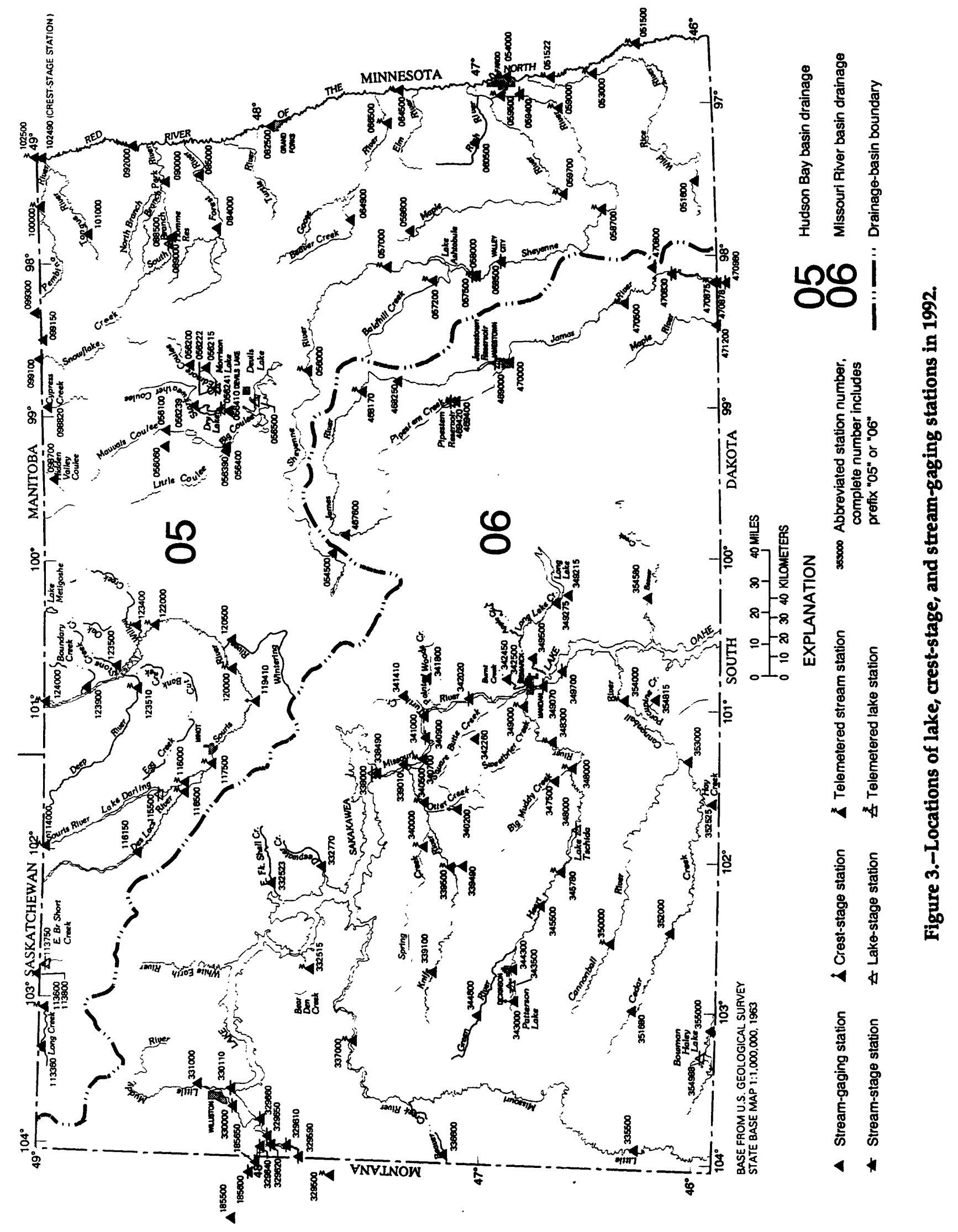


Table 3: Station-classification summary for 1992

\begin{tabular}{|c|c|}
\hline Station classification & Number of stations \\
\hline $\begin{array}{l}\text { Stream stations } \\
\text { Continuous record: } \\
\text { Stage and discharge } \\
\text { Stage only } \\
\text { Stage and peak flow } \\
\text { Partial record: } \\
\text { Discharge (seasonal) } \\
\text { Stage only (seasonal) } \\
\text { Peak (maximum flow only) }\end{array}$ & $\begin{array}{r}80 \\
11 \\
2 \\
22 \\
8 \\
7\end{array}$ \\
\hline $\begin{array}{l}\text { Lake and reservoir stations } \\
\text { Stage and contents } \\
\text { Stage only }\end{array}$ & $\begin{array}{r}10 \\
4\end{array}$ \\
\hline Total & 144 \\
\hline
\end{tabular}




\section{GROUND-WATER STATIONS}

PROJECT NUMBER: ND 00-002.

LOCATION: Statewide.

PERIOD OF PROJECT: Continuous.

PROJECT CHIEF: Russell E. Harkness.

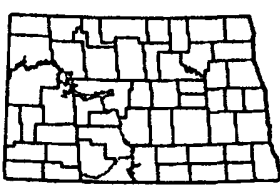

STATEWIDE

COOPERATING AGENCIES: (1) North Dakota State Water Commission; and (2) U.S. Department of the Army, Corps of Engineers.

PROBLEM: Planning for management and development of ground-water resources requires extensive knowledge of the occurrence and availability of ground water and use of and impacts on the ground-water system.

OBJECTIVES: The first objective is to collect water-level data sufficient to provide a minimum long-term data base. The data base is used for continued observation of the impacts of climatic variation and man's activities on the ground-water system. A statewide data base is essential for efficient resource management. The second objective is to provide a data base against which short-term records acquired in areal studies can be analyzed.

APPROACH: Evaluation of regional geology allows a general definition of aquifer systems and their boundary conditions. Within this framework and with some knowledge of (1) changes in the ground-water system in time and space and (2) the hydrologic properties of the aquifers, subjective decisions can be made in upgrading the statewide ground-water observation-well network. The ground-water observation-well network currently consists of about 750 wells. Of the 750 wells, about half are measured quarterly or more frequently and half are measured annually. The network can be refined as data become available and detailed areal studies of the ground-water system better define the aquifers, their properties, and the stresses to which they are subjected.

PROGRESS: All network data were collected on schedule. Water-level data from a basic network of wells (fig. 4) were prepared for publication.

PLANS FOR FISCAL YEAR 1993: Plans are to continue to operate the network and to perform scheduled well maintenance. Some adjustments will be made in the number of wells measured and in the frequency of measurements to satisfy the needs of the major cooperator.

REPORT PRODUCTS:

U.S. Geological Survey, 1992, Water-resources data, North Dakota, Water year 1991: U.S. Geological Survey Water-Data Report ND-91-1, 365 p.

U.S. Geological Survey, Water-resources data, North Dakota, Water year 1992 (in progress). 


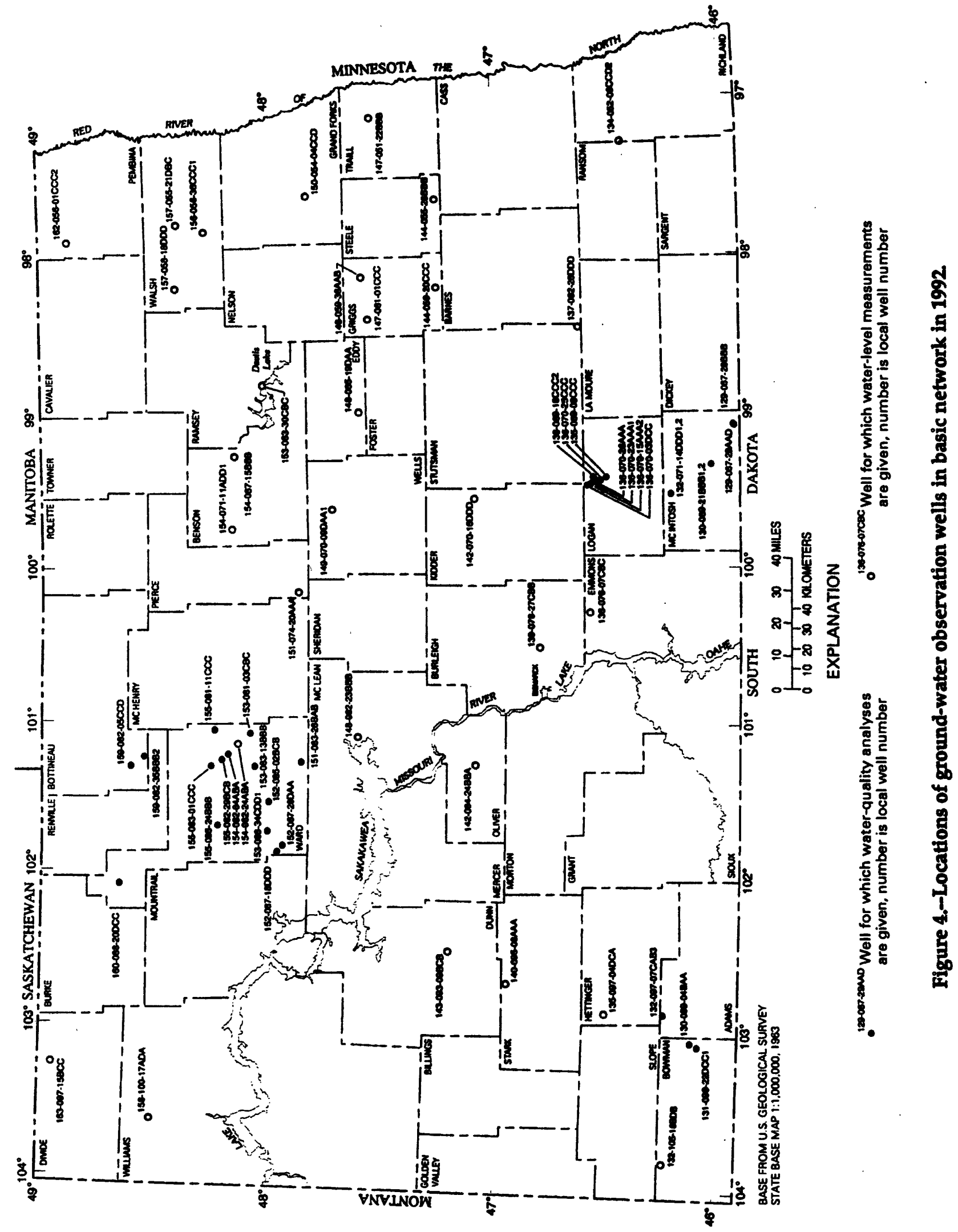




\section{WATER-QUALITY STATIONS}

PROJECT NUMBER: ND 00-003.

LOCATION: Statewide.

PERIOD OF PROJECT: Continuous.

PROJECT CHIEF: Russell E. Harkness.

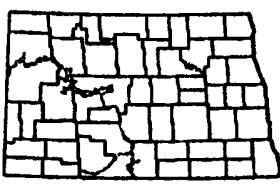

STATEWIDE

COOPERATING AGENCIES: (1) City of Minot; (2) North Dakota State Department of Health and Consolidated Laboratories; (3) North Dakota State Water Commission; (4) Three Affiliated Tribes; (5) U.S. Department of the Army, Corps of Engineers; (6) U.S. Department of the Interior, Bureau of Indian Affairs; (7) U.S. Department of the Interior, Bureau of Reclamation; and (8) U.S. Department of the Interior, Fish and Wildlife Service.

PROBLEM: Water-resources planning and water-quality assessment require a nationwide base level of relatively standardized information. For proper planning and assessment of the water resources, the chemical and physical qualities of surface water and ground water must be defined and monitored.

OBJECTIVES: Objectives are to (1) contribute to a national water-quality data base for use in broad Federal and State planning and management programs and (2) provide data for Federal and State management of interstate and international waters.

APPROACH: A network of water-quality stations will be operated to provide chemical concentrations, loads, and time trends as required by planning and management agencies.

PROGRESS: All network data were collected on schedule where possible, and records are being prepared for publication. The Refuge Monitoring Program in the Souris River basin for the U.S. Fish and Wildlife Service was modified to correspond with the constituent list and frequency of sampling recommended by the Souris River Bilateral Water-Quality Monitoring Group. Surface-water stations where water-quality data were collected are shown in figure 5.

PLANS FOR FISCAL YEAR 1993: Plans are to continue to operate the network with a few cooperator-requested modifications. A water-quality network established in 1992 will be continued in order to monitor water quality in Lake Sakakawea. A monthly monitoring site will be started on Lake Darling. One National Stream Quality Accounting Network (NASQAN) site will be discontinued because of funding reductions for this national network.

\section{REPORT PRODUCTS:}

U.S. Geological Survey, 1992, Water-resources data, North Dakota, Water year 1991: U.S. Geological Survey Water-Data Report ND-91-1, 365 p.

U.S. Geological Survey, Water-resources data, North Dakota, Water year 1992 (in progress). 


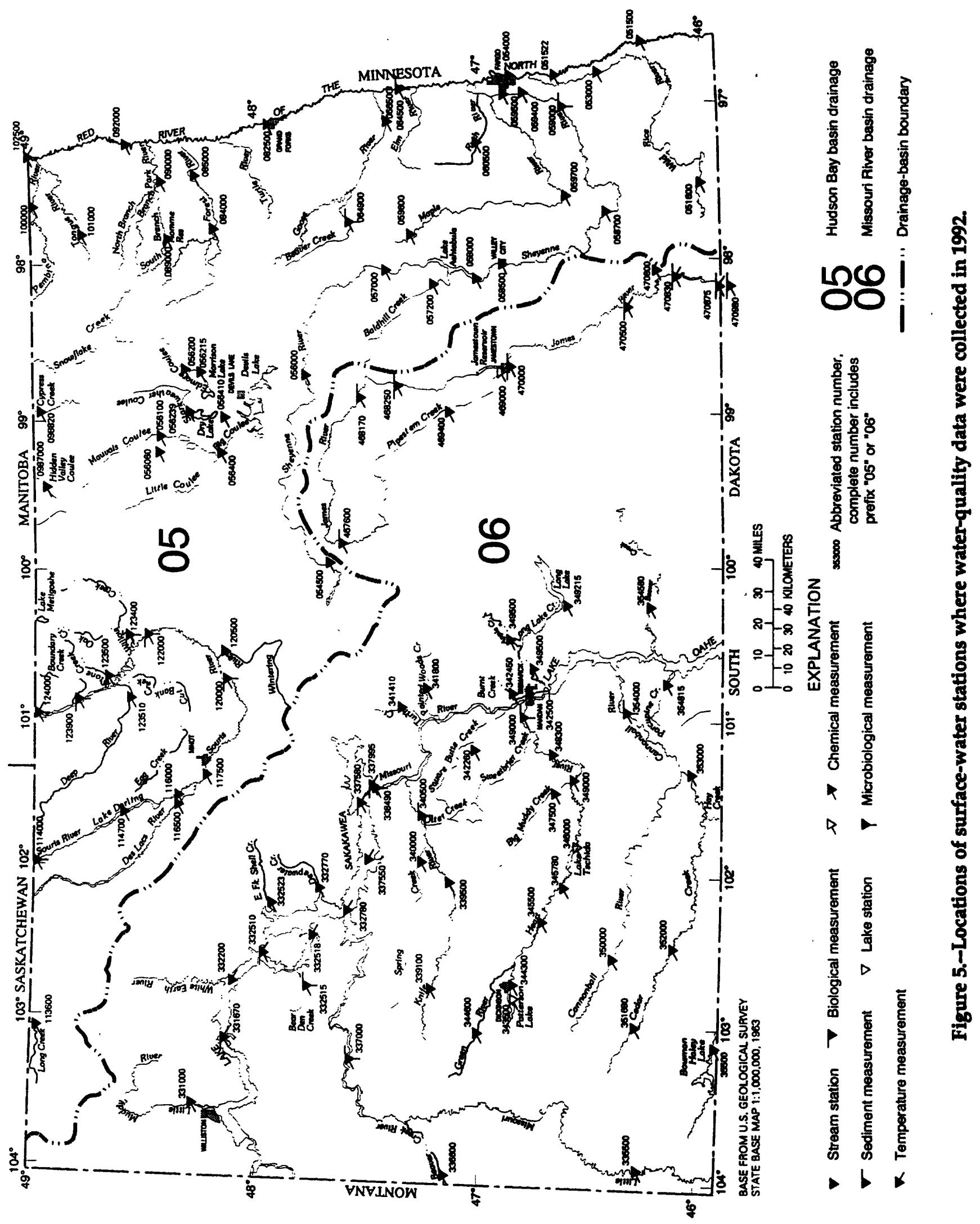




\section{SEDIMENT STATIONS}

PROJECT NUMBER: ND 00-004.

LOCATION: Statewide.

PERIOD OF PROJECT: Continuous.

PROJECT CHIEF: Russell E. Harkness.

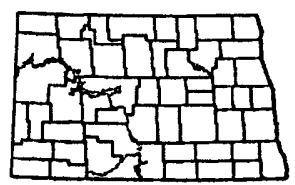

STATEWIDE

COOPERATING AGENCIES: (1) U.S. Department of the Interior, Bureau of Reclamation; and (2) other Federal agencies of the U.S. Department of the Interior for the development of the Missouri River basin.

PROBLEM: Water-resources planning for intrastate, as well as interstate, waters requires a standardized data base containing sediment transport information. The information must be accurate, unbiased, and available to the user.

OBJECTIVES: Objectives are to (1) contribute to a national sediment data base for use in broad Federal and State planning and management programs and (2) provide data for Federal management of interstate and international waters.

APPROACH: A network of sediment stations will be operated to provide spatial and temporal averages and trends of sediment concentration, sediment discharge, and particle size of sediment being transported by rivers and streams.

PROGRESS: All network data were collected and analyzed on schedule. Data were collected and analyzed for partial-record sediment stations shown in figure 5.

PLANS FOR FISCAL YEAR 1993: Plans are to continue to operate the network. One NASQAN site that is periodically sampled for sediment will be discontinued.

\section{REPORT PRODUCTS:}

U.S. Geological Survey, 1992, Water-resources data, North Dakota, Water year 1991: U.S. Geological Survey Water-Data Report ND-91-1, 365 p.

U.S. Geological Survey, Water-resources data, North Dakota, Water year 1992 (in progress). 


\section{NATIONAL TRENDS NETWORK FOR ATMOSPHERIC DEPOSITION}

PROJECT NUMBER: ND 00-005.

LOCATION: Statewide.

PERIOD OF PROJECT: Continuous.

PROJECT CHIEF: Bradley A. Sether.

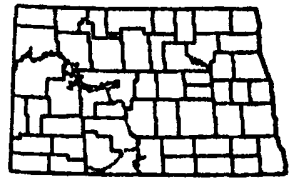

STATEWIDE

PROBLEM: In order to determine atmospheric fluxes within the hydrologic system and man's influences on these fluxes, it is necessary to establish and operate a nationwide, long-term network for monitoring atmospheric deposition of selected chemical constituents.

OBJECTIVES: Objectives are to (1) establish and operate a nationwide, long-term monitoring network to detect and measure levels of atmospheric deposition and (2) determine variations in atmospheric deposition that occur on a week-to-week basis by collection of wetand dry-deposition products for analysis of elements and constituents that can contribute to the chemical composition of surface waters.

APPROACH: Monitoring stations were operated at sites near Woodworth and at Icelandic State Park as part of the National Trends Network (NTN). Station equipment includes a wet/ dry precipitation collector, a paper-chart recording rain gage with event marker, and a weighing rain gage with an electronic data logger as a backup gage. Stations will be maintained, and onsite measurements of precipitation weight, specific conductance, and $\mathrm{pH}$ will be made. Samples will be collected, processed, and submitted to the National Atmospheric Deposition Program NTN Central Analytical Laboratory, Illinois State Water Survey. Data will be verified and stored in the NWIS. Results will be reported to the national program coordinator.

PROGRESS: Two atmospheric deposition stations were operated. Records for 1991 were published, and data for 1992 were reviewed for publication.

PLANS FOR FISCAL YEAR 1993: Station operation will continue. Data will be stored in NWIS files and published in the annual data report.

\section{REPORT PRODUCTS:}

U.S. Geological Survey, 1992, Water-resources data, North Dakota, Water year 1991: U.S. Geological Survey Water-Data Report ND-91-1, 365 p.

U.S. Geological Survey, Water-resources data, North Dakota, Water year 1992 (in progress). 


\title{
WATER-USE DATA ACQUISITION AND DISSEMINATION PROGRAM
}

\author{
PROJECT NUMBER: ND 00-007.
}

LOCATION: Statewide.

PERIOD OF PROJECT: Continuous.

PROJECT CHIEF: Kathleen M. Rowland.

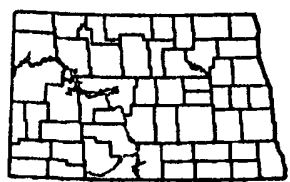

STATEWIDE

COOPERATING AGENCY: North Dakota State Water Commission.

PROBLEM: The water resources of North Dakota and the Nation are being used more extensively each succeeding year. In North Dakota, competition among users for available water resources in certain areas of the State has increased. In order to manage the development of the resources and to project future trends, planners and managers must be aware of existing patterns and quantity of use.

OBJECTIVES: Objectives are to (1) collect site-specific data to provide water-use information for the optimum utilization and management of the State's water resources; (2) store data collected so they may be retrieved at national, regional, and various local levels; and (3) disseminate water-use data to complement data on availability and quality of State and national water resources.

APPROACH: As an integral part of the water-permit program, the North Dakota State Water Commission collects site-specific water-withdrawal information from an annual inventory of permitted water users. Information on water withdrawals is stored in the following categories: public supply (includes municipal use and rural water systems), irrigation, and selfsupplied commercial and industrial (includes mining and thermoelectric).

The North Dakota State Water Commission and the U.S. Geological Survey conduct an ongoing cooperative program to contribute data to a U.S. Geological Survey national water-use data base. The North Dakota State Water Commission furnishes annual water-withdrawal information to the U.S. Geological Survey by magnetic tape. After the site-specific data are converted from State water-use categories to national water-use categories, the data are reformatted and stored in the U.S. Geological Survey's State Water Use Data System (SWUDS) and in the National Water Use Data System (NWUDS). As needed, amounts of nonpermitted water withdrawals for rural-domestic use and for agricultural use will be estimated based on human and animal population and per capita use.

PROGRESS: Data for "Water Use in the United States for 1990" were sent to headquarters for final review. Suggested changes to the 1990 data were made and the data were finalized for publication. Some updates were made to data currently in the SWUDS data base.

PLANS FOR FISCAL YEAR 1993: Data collection will continue. Readjustments will be made to the data-conversion program for the SWUDS data base. A water-resource investigation report will be prepared for the 1990 water-use data. Site-specific withdrawals will continue to be monitored. 


\section{REPORT PRODUCTS:}

U.S. Geological Survey, 1990, National water summary 1987-Hydrologic events and water supply and use: U.S. Geological Survey Water-Supply Paper 2350, 553 p.

Wesolowski, E.A., 1991, Estimated use of water in North Dakota in 1985 and trends during 1960-85: U.S. Geological Survey Water-Resources Investigations Report 89-4003, 1 p.

Estimated use of water in North Dakota in 1990 (planned). 


\section{BOARDS AND COMMISSIONS}

PROJECT NUMBER: ND 73-064.

LOCATION: Bismarck, North Dakota.

PERIOD OF PROJECT: Continuous.

PROJECT CHIEF: William F. Horak.

COOPERATING AGENCY: U.S. Department of State, International Joint Commission, Waterways Treaty Program.

PROBLEM: To coordinate water-resources activities with international, other Federal, State, and local agencies, District personnel participate on numerous boards and commissions. Participation frequently includes compiling, publishing, and disseminating meeting minutes or researching special concerns of participating agencies.

OBJECTIVES: Objectives are to (1) assure impartial Federal representation on the International Souris River Board of Control (International Joint Commission), the Souris River Bilateral Water-Quality Monitoring Group, and the Yellowstone River Compact Commission and (2) supply accurate, unbiased information to boards and commissions.

APPROACH: Chair the meetings and provide administrative support to the Yellowstone River Compact Commission. Serve as member for the United States to the International Souris River Board of Control and the Souris River Bilateral Water-Quality Monitoring Group. Furnish information requested by members of the International Souris-Red River Engineering Board.

PROGRESS: All meetings of the International Souris River Board of Control, the Souris River Bilateral Water-Quality Monitoring Group and its task forces, and the Yellowstone River Compact Commission were attended. The Yellowstone River Compact Commission annual report was published. The first annual report of the Souris River Bilateral Water-Quality Monitoring Group was prepared by the members and will be published and distributed in late 1992.

PLANS FOR FISCAL YEAR 1993: Plans are to continue attending board and commission meetings and to prepare the annual report of the Yellowstone River Compact Commission. The second annual report of the Souris River Bilateral Water-Quality Monitoring Group will be released. 


\section{EVAPORATION AND GROUND-WATER INTERACTION OF DEVILS LAKE, NORTH DAKOTA}

PROJECT NUMBER: ND 86-139.

LOCATION: Devils Lake basin, northeastern North Dakota.

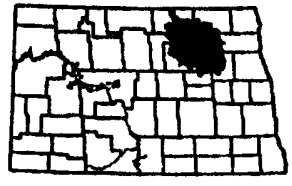

PERIOD OF PROJECT: April 1986 to September 1993.

PROJECT CHIEF: Gregg J. Wiche.

COOPERATING AGENCY: North Dakota State Water Commission.

PROBLEM: Historically, water levels of Devils Lake have fluctuated dramatically. In the early and mid-1980's, high water levels enabled the development of a multimillion-dollar fishing and tourist trade industry, but the high water threatened to inundate large areas of developed property. In the late 1980's and early 1990's, declining water levels have threatened the fishing industry. In order to develop a management model, State and local governments need information about how hydrologic components affect water levels. More information is needed on evaporation rates from the lake surface and on ground-water interaction.

OBJECTIVES: The purpose of this study is to measure the principal hydrologic components that cause water-level fluctuations of Devils Lake. The major emphasis will be to measure evaporation from Devils Lake and estimate the direction and magnitude of the groundwater flux component.

APPROACH: Evaporation will be computed with the energy-budget technique. Data that will be collected are incoming and reflected shortwave and longwave radiation, air temperature, dewpoint, water temperature of inlet streams, temperature and quantity of ground-water seepage, lake-surface temperature, and periodic temperature surveys of the entire water body to measure changes in stored heat. The ground-water flux will be estimated by installing a series of shallow water-table wells around Devils Lake in transects extending from the shoreline to the topographic divide.

PROGRESS: The interpretative phase of the project (1986-88) and the reports are complete. Data necessary to compute evaporation from the lake surface were collected for the 1992 water year. The project now is in a data-collection phase.

PLANS FOR FISCAL YEAR 1993: Collection of data necessary to compute mass-transfer evaporation will continue.

\section{REPORT PRODUCTS:}

Pusc, S.W., 1992, Ground water data: Interaction between ground water and a large terminal lake, Devils Lake, North Dakota: North Dakota State Water Commission Water Resources Investigation 12, $441 \mathrm{p}$.

Pusc, S.W., 1992, Interaction between ground water and a large terminal lake: Hydrogeology of Devils Lake area: North Dakota State Water Commission Water Resources Investigation 13, $95 \mathrm{p}$.

Sether, B.A., and Wiche, G.J., 1989, Meteorologic and hydrologic data collected for computing evaporation from Devils Lake, North Dakota, 1986-88: North Dakota State Water Commission Water Resources Investigation 10, 172 p. 
Wiche, G.J., 1992, Evaporation computed by energy-budget and mass-transfer methods and water-balance estimates for Devils Lake, North Dakota, 1986-88: North Dakota State Water Commission Water Resources Investigation 11, 52 p.

Hydrology of Devils Lake area, North Dakota (in progress). 


\section{RELATION BETWEEN UPPER-AIR FLOW PATTERNS, CLIMATE, AND HYDROLOGIC VARIABILTY IN THE RED RIVER OF THE NORTH BASIN, NORTH DAKOTA, SOUTH DAKOTA, MINNESOTA, MANITOBA, AND SASKATCHEWAN}

PROJECT NUMBER: ND 89-148.

LOCATION: Eastern North Dakota, northeastern South Dakota, northwestern Minnesota, southern Manitoba, southeastern Saskatchewan.

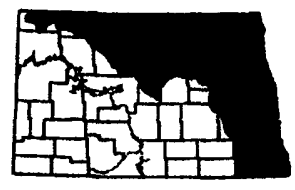

PERIOD OF PROJECT: March 1989 to September 1993.

PROJECT CHIEF: Gregg J. Wiche.

PROBLEM: In recent years, a general consensus has emerged that a global temperature increase larger than any in recorded history will occur late in the next century because of the doubling of the concentration of carbon dioxide (or the equivalent change from all radiatively active gases). Any significant change in the hydrologic flow regimen in the Red River of the North basin caused by carbon-dioxide-induced climate change could have an adverse effect on peak, mean, and low flows and on water quality of streams within the basin. Since the Red River of the North drains parts of Minnesota, South Dakota, and North Dakota and parts of Manitoba and Saskatchewan in Canada, a change in flow regimen of streams draining the Red River basin would raise difficult interstate and international legal questions.

OBJECTIVES: The hydrology of the Red River basin will be compared to the variability of 50-kilopascal height flow patterns over western and northern North America to (1) identify those anomalous conditions that can be classified as either hydrological or agricultural droughts and prolonged wet periods; (2) develop analyses of the 50-kilopascal height and 50- to 100-kilopascal thickness patterns for the northern hemisphere for the wet and dry periods; (3) assess the possible differences between the upper-air flow patterns that accompany wet and dry periods and compare the wet and dry upper-air flow patterns to the normal flow; (4) statistically compare climate variables such as temperature, precipitation, surface pressure, and cloud cover to the upper-air flow patterns and the discharge of the Red River of the North and its tributaries during wet and dry periods; and (5) assess the circulation controls that lead to the anomalies in the upper-air flow patterns associated with the anomalous periods.

APPROACH: The 50-kilopascal height and 50- to 100-kilopascal thickness patterns will be analyzed separately and compared to the normal patterns and to each other. The patterns that occurred during the prolonged wet and dry periods will be compared to the normal pattern. Descriptive statistics such as the mean, median, and standard deviation of the 50-kilopascal height and the 50- to 100-kilopascal thickness patterns will be computed. Statistics will be computed for the monthly discharge. The accumulated departure from the mean discharge will be calculated and plotted. Periods of greater-than-normal and less-than-normal discharge will be identified. The relations among wet and dry periods, discharge, and upper-air flow patterns will be determined.

PROGRESS: The progress and significant results are:

1. The analyses of the 50-kilopascal pressure surface composites (wet and dry cases) for each of the six subbasins in the Red River basin indicate that the Pacific-North American (PNA) teleconnection is the teleconnection most strongly related to anomalous precipitation in the basin. 
2. The PNA index for February-March wet cases for east of the Red River, west of the Red River, and the Assiniboine River subbasins was not strongly related to anomalous precipitation. The poor relation between the February-March 50-kilopascal pressure surface and the FebruaryMarch precipitation in the three subbasins is attributable, at least in part, to the transition from the typical winter upper-air flow pattern in February to the spring pattern in March.

3. The PNA and the Central Pacific (CP) were the only teleconnection indices directly related to the bimonthly precipitation.

4. The 50- to 100-kilopascal pressure surface thickness charts indicate that the mean temperature is greater than normal for the dry cases and less than normal for the wet cases.

5. The October-May 50-kilopascal anomaly patterns for years selected on the basis of streamflow were consistent for all of the subbasins. Thus, the PNA was negative for each of the 7 years that had the largest streamflow and positive for each of the 6 years that had the smallest streamflow.

PLANS FOR FISCAL YEAR 1993: Plans are to complete the review process and obtain Director's approval for publication of a journal article.

\section{REPORT PRODUCTS:}

Relation between upper-air flow patterns and hydrologic variability in the Red River of the North in the United States and Canada (in progress).

Relation between upper-air flow patterns, climate, and hydrologic variability in the Red River of the North basin, North Dakota, South Dakota, Minnesota, Manitoba, and Saskatchewan (in progress). 


\section{HYDROLOGY OF FORT BERTHOLD INDIAN RESERVATION, NORTH DAKOTA}

PROJECT NUMBER: ND 90-153.

LOCATION: Fort Berthold Indian Reservation, North Dakota.

PERIOD OF PROJECT: October 1989 to September 1993.

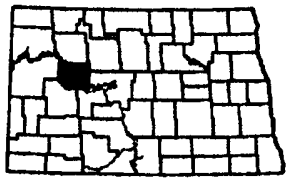

PROJECT CHIEF: Steve W. Cates.

COOPERATING AGENCY: Three Affiliated Tribes.

PROBLEM: Water of acceptable quality for domestic use is in high demand for the Fort Berthold Indian Reservation. Detailed information about the occurrence and quality of ground water and surface water on the reservation generally is not available or easily accessible.

OBJECTIVES: Objectives are to (1) describe the stratigraphy, distribution, and hydrologic properties of aquifers on the reservation; (2) investigate the quality and movement of ground water; (3) improve the understanding of the surface-water system; (4) complete an inventory of current water use; (5) prepare a report on results of the study; and (6) add data obtained during the study to an existing GIS data base.

APPROACH: Existing geologic, geochemical, and hydrologic data will be reevaluated. Streamflow will be measured, water-quality samples will be obtained, and selected spring and ground-water sites will be sampled and inventoried. Hydrologic and water-quality data will be analyzed, and test drilling will be conducted to augment existing data locations. Geophysical logs will be used to define locations of buried channels and buried glacial aquifers. Data will be integrated with other available data and used to interpret the reservation's water resources.

PROGRESS: Hydrologic data collection continued. Monthly measurements of streamflow, $\mathrm{pH}$, dissolved oxygen, water and air temperature, and specific conductance were made at gaging sites on East Fork Shell, Deepwater, Moccasin, Squaw, and Bear Den Creeks. Monthly water-level measurements were made at 45 wells in the ground-water monitoring network. More than 300 water-quality samples were collected from wells, springs, and streams on the Fort Berthold Indian Reservation.

Near-surface lithologic relations south of the Missouri River in the western part of the reservation (McKenzie, Dunn, and Mercer Counties) were closely examined. Several test holes were drilled in the McKenzie, Dunn, and Mercer Counties area of the reservation. Of these holes, eight were completed as observation wells. A total of eight test holes were drilled on the basis of high-accuracy gravity data acquired in the area of the reservation underlain by buriedvalley aquifers.

A reconnaissance of springs indicated that the majority of springs emanated from lignite outcrops. The recharge area for the springs is relatively small and, thus, water resources from springs are limited.

Evaluation of the Parshall, Shell Creek, and White Shield aquifers was completed.

PLANS FOR FISCAL YEAR 1993: Data compilation will be completed. The final report will be processed through Director's approval. 


\section{REPORT PRODUCTS:}

Hydrologic data of Fort Berthold Indian Reservation (in progress).

Hydrology of Fort Berthold Indian Reservation (in progress). 


\section{PREDICTING SCOUR AT BRIDGE CROSSINGS ON STREAMS IN NORTH DAKOTA}

PROJECT NUMBER: ND 90-155.

LOCATION: Statewide.

PERIOD OF PROJECT: June 1990 to September 1994.

PROJECT CHIEFS: Douglas G. Emerson and Tara J. Williams-Sether.

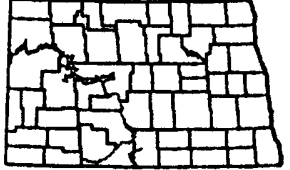

STATEWIDE

COOPERATING AGENCY: North Dakota Department of Transportation.

PROBLEM: Bridge designers need more reliable methods to predict bridge scour. Most of the existing scour-prediction equations are based on scale-model bridge-scour measurements. The equations have not been validated because of the lack of onsite measurements, which are difficult to collect during high-flow conditions. Data bases that reflect full-scale, prototype field conditions are needed to determine which scour-prediction equations should be used for a particular set of conditions.

OBJECTIVES: Objectives are to (1) measure flow and scour during high-flow conditions to define the occurrence and extent of scour at 20 selected bridge sites, (2) compare scour depths measured onsite with scour depths estimated using published scour-prediction equations and evaluate the adequacy of the scour-prediction equations, (3) use regression analyses and(or) other curve-fitting techniques to attempt to develop improved scour-prediction equations if current equations fail to accurately estimate scour in North Dakota and if adequate scour data are collected, and (4) evaluate an additional 20 bridge sites for scour.

APPROACH: A total of 20 scour-measurement bridge sites will be selected. Bridge-scour measurements will be made during high-flow conditions for 3 years. The collected bridge-scour data will be used to evaluate existing scour-prediction equations or to attempt to develop improved scour-prediction equations. An additional 20 bridge sites will be selected for scour evaluation. The 20 scour-evaluation bridge sites will be evaluated according to Federal Highway Administration guidelines.

PROGRESS: The 20 scour-measurement bridge sites were monitored for high flow and scour. No significant flooding or scouring occurred during 1992. Scour gages were installed on bridge piers at the streamflow-gaging station Cannonball River at Breien, N. Dak., to help monitor scour in case of significant flow. All scour evaluations have been completed according to Federal Highway Administration guidelines.

PLANS FOR FISCAL YEAR 1993: The 20 scour-measurement bridge sites will continue to be monitored for high flow and scour. 


\section{EFFECTS OF EVAPOTRANSPIRATION ON PESTICIDE DISTRIBUTIONS AND TRANSPORT IN THE UNSATURATED ZONES OF NORTHERN CORNBELT SAND PLAINS}

PROJECT NUMBER: ND 91-157.

LOCATION: Southeastern North Dakota and east-central Minnesota.

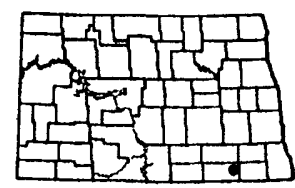

PERIOD OF PROJECT: March 1991 to September 1993.

PROJECT CHIEF: Stephen C. Komor.

PROBLEM: In many agricultural areas, pesticides are transported into ground-water aquifers by water that infiltrates through the unsaturated zone. To understand how pesticides enter ground-water aquifers, transport mechanisms and distribution of water and pesticides in the unsaturated zone must be documented. One little-studied aspect of this subject is the effects of evapotranspiration on pesticide transport and distribution.

OBJECTIVE: The objective of this study is to document the effects of evapotranspiration on pesticide transport and distribution in the unsaturated zones of unconfined sand-plain aquifers.

APPROACH: Field experiments to measure evapotranspiration effects will be conducted at the Northern Cornbelt Sand Plain Management System Evaluation Area (MSEA) test site near Oakes, N. Dak, and at the MSEA test site near Princeton, Minn. The pesticide atrazine will be used in the experiments. At each site, time-domain reflectometer probes will be used to provide constant monitoring of soil-water content. Evapotranspiration will be measured with lysimeters. Pore water from soil cores will be analyzed for oxygen and hydrogen stable-isotope values. The isotope data will provide evapotranspiration rates and indicate the thickness of the surface soil layer where water movement is by vapor diffusion. Other soil cores will be collected and analyzed for total atrazine content. The atrazine concentrations will be correlated with the information about evapotranspiration rates and water-transport mechanisms to identify the effects of evapotranspiration rates on atrazine distributions. In the first year, the experiments will be conducted in an uncropped area of bare soil. In the second year, the experiments will be repeated in an area planted with corn.

PROGRESS: Second-year field experiments were conducted to determine the effects of evapotranspiration on atrazine transport through unsaturated soil. The experiments were conducted near Oakes, N. Dak., and Princeton, Minn., on 30- by 30-meter soil plots.

PLANS FOR FISCAL YEAR 1993: None. The project has been completed except for the final report, which will be completed jointly with the Minnesota district.

\section{REPORT PRODUCTS:}

Komor, S.C., and Emerson, D.G., 1992, Atrazine and bromide movement through unsaturated sand plains at sites in Minnesota and North Dakota: Proceedings, North Dakota Water Quality Symposium, March 25-26, 1992, Bismarck, N. Dak., p. 27.

Effects of evapotranspiration on movement of water, atrazine, and bromide in unsaturated sandy soils (in progress). 


\section{HYDROLOGIC AND HUMAN ASPECTS OF THE 1988-92 DROUGHT IN NORTH DAKOTA}

PROJECT NUMBER: ND 91-158.

LOCATION: Statewide.

PERIOD OF PROJECT: July 1991 to September 1993.

PROJECT CHIEF: Douglas G. Emerson.

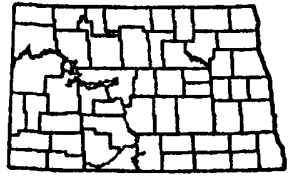

STATEWIDE

COOPERATING AGENCY: North Dakota State Water Commission.

PROBLEM: The impacts of the 1988-92 drought are causing major economic problems in North Dakota. Many reservoirs are at extremely low levels. Water levels in many shallow aquifers are at or near period-of-record lows. In some of these aquifers, well yields may be reduced, particularly from wells that do not penetrate the full saturated thickness of the aquifer. A large percentage of prairie potholes are dry. Some cities have had restrictions on water use, and a few have had water trucked from other sources. Local, State, and Federal water-resources managers need up-to-date information to evaluate and manage programs during periods of hydrologic extremes. Thus, it is necessary to document the severity of the 1988-92 drought and its impacts on North Dakota water resources. Managers need this information to manage current programs and for reference when managing future programs.

OBJECTIVE: The objective of this study is to describe the severity of the 1988-92 drought by documenting the drought as a hydrologic event, documenting how impacts of the drought affected people, and comparing the drought to previous droughts.

APPROACH: Description of the 1988-92 drought will include a chronology of the drought as a hydrologic event. The drought will be documented both temporally and spatially for the State. The documentation will include information and analyses, such as (1) accumulative departure from normal precipitation for selected sites, (2) low-flow frequency curves for selected streams, (3) accumulative departure from normal streamflow for selected streams, (4) waterlevel trends for selected observation wells, and (5) changes in the Palmer drought index during the drought. Impacts of the 1988-92 drought on people will be documented. Impacts on the following categories will be addressed: (1) Public water supplies, (2) rural water supplies, (3) irrigation and agriculture, (4) water quality, (5) fisheries and wildlife, and (6) recreation. Most accounts of the impacts on people will be obtained from State and local agencies and from news media. A comparison of the 1988-92 drought to previous droughts will include many of the same indexes used to document the 1988-92 drought. Additional analyses will include waterlevel trends of Devils Lake. The major North Dakota droughts that would be compared to the 1988-92 drought are those that occurred during the 1930's, the 1960's, and the 1970's.

PROGRESS: Evaluation of the 1988-92 drought and comparisons with past droughts continued. A draft of the report is being prepared.

PLANS FOR FISCAL YEAR 1993: Evaluation of the 1988-92 drought and comparisons with past droughts will be completed. The report will be processed through Director's approval, and publication of the report is anticipated.

REPORT PRODUCTS:

Documentation of the 1988-92 drought in North Dakota (in progress). 


\section{EFFECTS OF BOTTOM SEDIMENTS ON NUTRIENT CYCLES IN DEVILS LAKE}

PROJECT NUMBER: ND 91-159.

LOCATION: Northeastern North Dakota.

PERIOD OF PROJECT: June 1991 to October 1992.

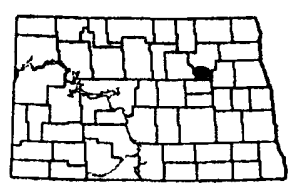

PROJECT CHIEF: Robert M. Lent.

COOPERATING AGENCIES: (1) North Dakota Game and Fish Department, (2) North Dakota State Department of Health and Consolidated Laboratories, and (3) North Dakota State Water Commission.

PROBLEM: Extreme drought conditions during 1988 and moderate drought conditions during 1989-90 have resulted in a dramatic decline in the level of Devils Lake. Concurrent with the decline in the water level was the occurrence of aesthetically unpleasant algal blooms that adversely affect the sport fisheries, migratory waterfowl, and recreational activities on Devils Lake. In response to numerous requests from local and national fishing, hunting, recreational, and environmental organizations, State and Federal agencies are evaluating the feasibility of importing water to stabilize the lake level and to alleviate potential water-quality problems. The feasibility study should address the specific processes that are responsible for the algal blooms in the lake.

OBJECTIVES: The primary purpose of this study will be to determine the processes that are responsible for the increase in nutrient concentrations in Devils Lake and for the concurrent algal blooms. Objectives are to (1) determine the seasonal variability of diffusive fluxes of selected chemical constituents from the bottom sediment into the water column, (2) describe the basic nutrient cycles in Devils Lake, (3) measure the phytoplankton primary productivity rates at selected times throughout the year, and (4) calculate the chemical mass balances for major ions and nutrients four times for 1 year of sampling. The study will result in an increased understanding of nutrient cycling in Devils Lake and allow an evaluation of the problems of eutrophication and algal blooms.

APPROACH: Pore-water diffusive-flux rates of major ions and nutrients will be measured. Composition of material settling from the photic zone and from the lower parts of the water column to the bed of the lake and the rate at which settling occurs will be measured by using sediment traps deployed near the bottom of the photic zone or just above the lake bottom. The primary productivity rates in Devils Lake will be monitored, and the ambient geochemical conditions in the lake that are responsible for the algal blooms will be identified. Geochemical modeling will be used to calculate mass balances for various constituents.

PROGRESS: The draft of the final report has been prepared and submitted for review.

PLANS FOR FISCAL YEAR 1993: Plans are to complete the review process and obtain Director's approval for publication of the report.

\section{REPORT PRODUCTS:}

Lent, R.M., and Wald, J.D., 1992, Importance of bottom-sediment diffusive fluxes to chemical budget of Devils Lake, North Dakota: Proceedings, North Dakota Water Quality Symposium, March 25-26, 1992, Bismarck, N. Dak., p. 167.

Seasonal and spatial variability in bottom-sediment diffusive fluxes in Devils Lake, North Dakota: Implications to major-ion and nutrient cycles (in progress). 


\section{EVALUATION OF HYDROCARBON AND CAPILLARY FRINGE THICKNESS AND POTENTIAL FOR CONTAMINANT MOVEMENT IN THE UPPER AQUIFER SYSTEM IN THE VICINITY OF THE FLYING J FACILITY, WILLISTON, NORTH DAKOTA}

PROJECT NUMBER: ND 91-161.

LOCATION: Northwestern North Dakota.

PERIOD OF PROJECT: July 1991 to September 1992.

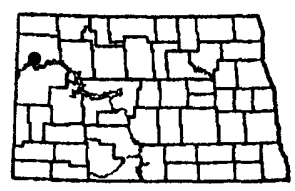

PROJECT CHIEF: Edwin A. Wesolowski.

COOPERATING AGENCY: U.S. Environmental Protection Agency.

PROBLEM: In May 1991, the U.S. Environmental Protection Agency completed a technical review of a Resource Conservation and Recovery Act (RCRA) Facility Investigation report for the Flying J refinery site near Williston, N. Dak. The U.S. Environmental Protection Agency requested assistance from the U.S. Geological Survey to do a detailed evaluation of selected technical information in the report.

OBJECTIVES: Objectives are to (1) evaluate the hydrocarbon thickness for the upper aquifer system and (2) evaluate the Modular Three-Dimensional Finite-Difference GroundWater Flow Model (MODFLOW) application used to simulate ground-water flow and potential movement of contaminants in the vicinity of the Flying J Facility.

APPROACH: A literature search will be conducted to identify methods and limitations of calculating light nonaqueous phase liquid (LNAPL) and capillary fringe thicknesses. On the basis of the literature search, LNAPL and capillary fringe thickness calculations as reported in the current (1991) RCRA Facility Investigation report will be evaluated. Where appropriate data exist, independent calculations of LNAPL and capillary fringe thicknesses will be made.

Numerical modeling and selected migration pathways reported in the April 1991 RCRA Facility Investigation report will be reviewed.

PROGRESS: The final report was edited and colleague reviews were completed.

PLANS FOR FISCAL YEAR 1993: Plans are to complete the review process and obtain Director's approval to release an administrative report to the U.S. Environmental Protection Agency. 


\title{
MECHANISMS THAT CONTROL SEEPAGE OF SALINE GROUND WATER THROUGH GLACIAL CONFINING UNITS BENEATH THE RED RIVER OF THE NORTH AND ITS TRIBUTARIES
}

\author{
PROJECT NUMBER: ND 91-162.
}

LOCATION: Northeastern North Dakota and northwestern Minnesota.

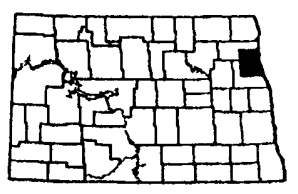

PERIOD OF PROJECT: January 1991 to September 1993.

PROJECT CHIEF: Michael L. Strobel.

PROBLEM: Discharge of saline water from bedrock aquifers underlying the Pleistocene deposits in the Red River of the North valley in northeastern North Dakota and northwestern Minnesota is indicated by large areas of saline soils and saline-rich wetlands throughout the northern part of the valley. The contribution of the discharge from bedrock aquifers to the water quality of surface-water sources, such as the Red River of the North and its tributaries, is not well documented. An evaluation of the geohydrologic factors acting within the basin would benefit the overall analysis and assessment of the water quality in the Red River of the North.

OBJECTIVES: The purpose of this study is to evaluate the effects of upward migration of ground water from bedrock sources through surficial Pleistocene deposits on the water quality of the Red River of the North. Objectives are to (1) evaluate the geologic and hydrologic properties of the surficial Pleistocene deposits at sites characteristic of either small or large hydraulic conductivities that control seepage from the bedrock aquifers and (2) use the sitespecific data through the application of ground-water flow models to estimate the regional effects of ground-water discharge on the quality and quantity of streamflow in the Red River of the North and its tributaries.

APPROACH: Three well sites will be selected to study the hydraulic properties of the Pleistocene deposits. The sites will represent areas of glacial-lacustrine deposits that have large hydraulic conductivities, glacial-lacustrine deposits that have small hydraulic conductivities, and glacial deposits near the margins of the Red River of the North valley that are not overlain by lacustrine deposits. Pumping tests from nested wells screened at various depths at each site will provide hydrologic data that will be applied to a two-dimensional cross-sectional groundwater flow model through the three sites. Data from this study, in addition to other historical data, will be applied to a three-dimensional regional ground-water flow model that encompasses the upper part of the Red River of the North drainage basin.

PROGRESS: Water levels in wells were monitored on a regular basis, cores were mapped in detail, and texture analysis was completed by a laboratory at the University of North Dakota. Water samples from all wells were collected and analyzed for major ions. Numerous specificconductance and discharge measurements were made on major tributaries in the study area, and hydraulic conductivities of various surficial deposits in the area were assessed using slug tests (pumping tests are presently being conducted). Flowing wells are presently being field located and inventoried. A two-dimensional cross-sectional ground-water flow model was constructed through the three well sites. Results of the drilling and core analysis were presented as a poster at the North Dakota Water Quality Symposium in Bismarck, N. Dak., during March 1992. Results of the surface-water analysis and general problem overview were presented as a paper at the same symposium session and are published in symposium proceedings. Results of the ground-water chemistry and two-dimensional flow model were presented at the Geological Society of America Annual Meeting in Cincinnati, Ohio, in October 1992. 
PLANS FOR FISCAL YEAR 1993: Plans are to complete the hydraulic analysis of the three well sites, continue water-level monitoring, improve the two-dimensional cross-sectional ground-water flow model and construct a three-dimensional regional ground-water flow model, complete an inventory of flowing wells, and publish the final report.

\section{REPORT PRODUCTS:}

Strobel, M.L., and Gerla, P.J., 1992, Effects of saline ground-water discharge on water quality of the Red River of the North, northeastern North Dakota: Proceedings, North Dakota Water Quality Symposium, March 25-26, 1992, Bismarck, N. Dak., p. 60-82.

Strobel, M.L., Luther, M.R., and Boespflug, K.L., 1992, Correlation of texture and thickness of Pleistocene sediments to the presence of saline soils and wetlands and to surface-water quality in the Red River of the North basin, North Dakota: Proceedings, North Dakota Water Quality Symposium, March 25-26, 1992, Bismarck, N. Dak., p. 248.

Hydrogeological restrictions to saline ground-water discharge in the Red River of the North drainage basin, North Dakota (in progress).

Data records and methods of investigation (planned). 


\section{NATIONAL WATER-QUALITY ASSESSMENT, RED RIVER OF THE NORTH BASIN}

PROJECT NUMBER: ND 92-163.

LOCATION: Northwestern Minnesota and eastern North Dakota.

PERIOD OF PROJECT: Continuous.

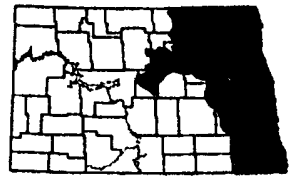

PROJECT CHIEF: Norman D. Haffield.

PROBLEM: Federal, State, and local governments and industry have made significant commitments to the protection of water quality over the past 2 decades. Large financial investments have been made for water-quality management and protection over the past 20 years and future expenditures are anticipated to abate and control water pollution. Nationally consistent information is needed to make valid regional comparisons and national statements about current water-quality conditions and about changes in these conditions. The U.S. Geological Survey began implementing a full-scale National Water-Quality Assessment (NAWQA) program in 1991 to address this need for national water-quality information. Because it would be impractical to assess water quality in every area of the Nation, major activities of the NAWQA program will be conducted within a set of hydrologic systems called study units. The Red River of the North basin was selected as 1 of 60 study units because (1) the basin represents an important hydrologic region where good quality water is a valued resource vital to the region's economy; (2) the water quality of the Red River of the North, which flows north into Manitoba, Canada, is of international concern; (3) the basin represents a significant agricultural area in keeping with the President's Water-Quality Initiative and provides opportunities to study sediment, nutrients, and pesticides through the national assessment part of NAWQA; and (4) the northern location and potential interaction of surface and ground water are essential physical factors necessary for a complete national assessment of water quality.

OBJECTIVES: The purpose of this study is to describe the status and trends in the quality of a large, representative part of the basin's surface-water and ground-water resources and to provide a sound, scientific understanding of the primary natural and human factors affecting the quality of these resources. Objectives are to (1) identify the regional physical, chemical, and biological constituents of water quality (herein called target constituents) that are of concern in the Red River of the North study unit; (2) estimate the distribution and annual stream load of selected pesticides, nutrients, and sediment in the basin; (3) describe the relation of water quality to regional land-use practices in surficial and confined aquifers within the glacial drift and in major streams; (4) identify the predominant natural and human factors that affect the load and concentration of target constituents measured in water and aquatic animals; (5) describe seasonal variability of selected target constituents in major streams from agricultural runoff and from natural sources; (6) describe the long-term regional and subregional trends of target constituents in surface water and ground water; and (7) design sampling schemes of surface water, ground water, and aquatic animals to effectively monitor for long-term trends in water quality.

APPROACH: Project activities will be cyclic to accomplish the water-quality status and trends components of the study. The first 2 years will focus on planning and analysis of available data. The next 3 years will emphasize data collection and analysis. The following year will be used for report preparation. A lower level of data collection will continue for the subsequent 5 to 6 years to evaluate long-term trends in water quality after which the more intensive data-collection cycle will be repeated. Project planning will be coordinated through a 
liaison committee made up of State, local, and other Federal agencies and some Canadian agencies and private industries who will help identify key water-quality issues of the basin and sources of data and will assist with the project design. Large amounts of available water-quality and ancillary data will be compiled into computer data bases, including GIS data bases, for spatial comparisons and statistical analysis. Information from the available data will be used to design data collection needed to accomplish a comprehensive assessment of the basin water quality. Water will be sampled from networks of fixed and synoptic stream stations and wells and analyzed for target constituents. Suspended and bottom sediments will be collected from major streams and analyzed for grain-size distribution and selected chemical constituents. Algae and tissues of fish and macroinvertebrates will be sampled and analyzed for selected trace metals and organic pollutants. Short reports of significant findings will be prepared on specific water-quality topics throughout the study. A larger report summarizing results of the first 6year cycle of the study will be completed in the seventh year.

PROGRESS: Staffing for the project office in St. Paul, Minn., the field office in Grand Forks, N. Dak., and the office in Bismarck, N. Dak., was completed. Liaison-committee members of the project reviewed and commented on the study work plan and were provided with preliminary results from reconnaissance sampling of streams. General sampling design, which included a plan to subdivide the Red River of the North basin into physiographic and ecological categories, was completed for the next 3 years of data collection. In December 1991, stream sampling and flow measurements indicated that three small tributaries in northeastern North Dakota contributed 30 percent of the dissolved-solids load but only 5 percent of the streamflow of the Red River of the North. A water-quality reconnaissance was completed during the summer. More than 100 stream sites were visited for consideration as monitoring locations for water, sediment, and biologic sampling. Ecological descriptions of selected stream reaches were begun. Fine-grained stream-bottom materials and fish tissue were sampled throughout the basin in August and submitted to the national water-quality laboratory for analysis of a large suite of organic compounds and trace metals. Water-quality data available from Storage Retrieval (STORET) and some State data bases were collated and entered into a central computer data base. Available ancillary data, such as physiography, hydrography, land use, soils associations, hydrologic-structure locations, hydrogeology, climate, and ecoregions were obtained and processed into a GIS. The available data and reports were reviewed to prepare the first draft of a report describing the environmental setting of the Red River of the North basin as it relates to regional water quality. A report that describes the distribution of nutrients, sediment, and pesticides in surface and ground water based on available data also was started. A project description and overall study approach were presented at the Minnesota Water 1992 conference and the 1992 North Dakota Water Quality Symposium.

PLANS FOR FISCAL YEAR 1993: Plans for sampling networks to collect water-quality data will be finalized for the next 3 years of effort. Beginning in the winter of 1993, water samples will be collected from selected stream sites to evaluate water quality that represents various seasonal and runoff conditions. Sites will be selected to evaluate runoff from land uses and land cover such as cropland, mixed forest and cropland, rangeland, wetland, and urban areas. Some stream sites will be sampled to evaluate the integration of runoff from numerous landscapes. Ecological surveys, which include habitat assessment, biological-community surveys, and fish sampling, will be started at selected stream reaches. Computer records of water wells will be consolidated into a single project data base and reviewed to select wells for water sampling. Some wells will be installed along ground-water flow paths and sampled to evaluate in more detail the distribution of ground-water quality beneath principal land uses and near discharge to streams. Data collected on water chemistry, sediment, and aquatic biota will 
be analyzed and compared to natural and landscape features. This analysis also will be used to refine specific approaches and sampling networks to collect additional water-quality data. Communication of project plans and preliminary findings and information exchange will continue through the liaison-committee process.

\section{REPORT PRODUCTS:}

Cowdery, T.K., and Brigham, M.E., 1992, Baseflow dissolved-solids loads to streams of the Red River of the North basin, South Dakota, North Dakota, and Minnesota: Proceedings, Midwest Ground Water Conference, Sioux Falls, S. Dak., October 15-16, 1992.

Lorenz, D.L., 1992, Using a geographic information system to describe the environmental setting of the Red River of the North basin, in Balthrop, B.H., and Baker, E.G., comps., U.S. Geological Survey National Computer Technological Meeting Program and Abstracts, May 1722, 1992, Norfolk, Virginia: U.S. Geological Survey Open-File Report 92-64, 41 p.

Stoner, J.D., 1991, National water-quality assessment program, Red River of the North: U.S. Geological Survey Open-File Report 91-151, 1 p.

Stoner, J.D., and Lorenz, D.L., 1992, Water-quality assessment strategy for the Red River of the North basin, North Dakota, South Dakota, and Minnesota: Proceedings, North Dakota Water Quality Symposium, Bismarck, N. Dak., March 25-26, 1992, p. 291.

Tornes, L.H., Lorenz, D.L., Brigham, M.E., and Stoner, J.D., 1992, Plans for a water-quality assessment of the Red River of the North basin, Minnesota, North Dakota, and South Dakota: Proceedings, Minnesota Water 1992 Conference, Minneapolis, Minn., February 13-14, 1992.

Environmental setting of the Red River of the North basin and its implications for water quality (planned). 


\section{CHRONOLOGY OF MERCURY LOADING TO DEVILS LAKE, NORTH DAKOTA, INFERRED FROM SEDIMENT CORE DATA}

PROJECT NUMBER: ND 92-164.

LOCATION: Northeastern North Dakota.

PERIOD OF PROJECT: December 1991 to September 1993.

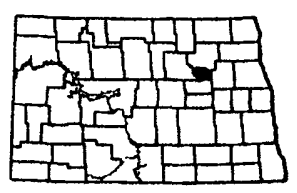

PROJECT CHIEF: Robert M. Lent.

COOPERATING AGENCY: North Dakota State Department of Health and Consolidated Laboratories.

PROBLEM: Recent information provided by the North Dakota State Department of Health and Consolidated Laboratories indicates that mercury concentrations in sport fish collected from Devils Lake, N. Dak., are above background levels (as much as 1.84 micrograms per gram in large walleyes). Devils Lake is the terminal lake in a large closed drainage basin (about 9,900 square kilometers) located in northeastern North Dakota. Devils Lake is relatively shallow; depths rarely exceed 10 meters. Recreational fishing on Devils Lake is a major tourist industry vital to the economy of the area. However, high concentrations of mercury in fish may represent a potential health risk to specific segments of the general population. Unfortunately, little is known about the sources of mercury to the lake, the present and historic rates of mercury loading to the lake, and the total amount of mercury stored in bottom sediments. These unknowns all are critical for developing a sound management plan designed to address the problem of mercury contamination in Devils Lake and throughout North Dakota.

OBJECTIVES: The objective of this study is to use sediment core data to construct chronologies of mercury accumulation rates in Devils Lake. These data will represent the only historic record of mercury contamination in the Devils Lake area. Once established, the chronologies of mercury accumulation rates in Devils Lake can be used to clarify a variety of issues, including preindustrial and modern levels of mercury loading to the lake, timing of increased mercury loading, and the total amount of mercury in the sediments. The information from individual cores will be compared to identify possible sources of the mercury to Devils Lake.

APPROACH: Sediment cores will be collected at six sites in the Devils Lake drainage basin, including Sweetwater Lake, Creel Bay, Main Bay, East Bay, East Devils Lake, and Stump Lake. These sites were chosen to represent the entire range of water-quality conditions currently existing in Devils Lake. The cores will be extruded vertically and sectioned into 1-centimeter horizons at the field station. The samples will be prepared for radioisotopic analysis for sedimentation-rate determinations, analysis of mercury, and supplemental data. Supplemental data include total organic carbon, other trace metals, and carbonate minerals.

PROGRESS: Field and laboratory work was completed. Results of laboratory analyses have been compiled, and records of mercury accumulation in the basin have been calculated.

PLANS FOR FISCAL YEAR 1993: An interpretative report describing results of this study will be prepared and processed through Director's approval.

\section{REPORT PRODUCTS:}

Chronologies of mercury loading to Devils Lake, North Dakota, inferred from sediment core data (planned). 


\section{HYDROLOGY OF THE FORT TOTTEN INDIAN RESERVATION, NORTH DAKOTA}

PROJECT NUMBER: ND 92-165.

LOCATION: Fort Totten Indian Reservation, North Dakota.

PERIOD OF PROJECT: June 1992 to September 1995.

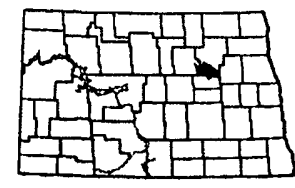

PROJECT CHIEF: Edwin A. Wesolowski.

COOPERATING AGENCY: Devils Lake Sioux Tribe.

PROBLEM: Water plays an important role in most aspects of life on the Fort Totten Indian Reservation. Water of acceptable quality for domestic use is in particularly crucial demand. The Devils Lake Sioux Tribe of the Fort Totten Indian Reservation is interested in resolving questions about the availability of water resources on the reservation and in developing a watermanagement plan. However, detailed information on the hydrology of the reservation generally is not available or easily accessible.

OBJECTIVES: Objectives are to (1) compile all existing geologic, hydrologic, waterquality, water-use, and relevant ancillary data for the reservation, verify the data, and store the data in digital formats that are readily accessible to facilitate retrieval and processing by GIS software; (2) describe the distribution, geology, and hydrologic properties of aquifers that exist on the reservation; (3) investigate the Warwick aquifer in detail by identifying and evaluating directions of ground-water movement, areas of recharge and discharge, interrelations with surface water, hydrologic properties of the aquifer, and quantity and quality of ground water in storage; (4) improve the understanding of the surface-water system by documenting storage and water quality in lakes, ponds, and streams; (5) inventory water use on the reservation; and (6) develop and calibrate a ground-water flow model of the Warwick aquifer to evaluate concepts of the flow system and to identify potential effects of increasing withdrawals from the aquifer on ground-water levels, recharge, and potential ground-water contamination.

APPROACH: Existing geologic, geochemical, and hydrologic data will be reevaluated. Test drilling will be conducted to augment existing hydrogeologic data. Ground-water levels, lake levels, and streamflow will be measured. Water-quality samples will be obtained and analyzed. Data on water levels, aquifer thickness and areal extent, and aquifer hydraulic properties will be used to construct a digital ground-water flow model of the Warwick aquifer.

PROGRESS: GIS coverages for geologic, hydrologic, and cultural features of the reservation were developed. Existing data were compiled, verified, and stored for later use in basic-data and interpretative reports. A conceptual model and water budget for the Warwick aquifer were developed. A well-monitoring network was developed and monthly measurements were begun.

PLANS FOR FISCAL YEAR 1993: Generally, work on the Warwick aquifer will be emphasized, but selected data collection from existing wells for the entire reservation will continue. Evaluation of existing well-log, geophysical-log, and water-level data will continue, and the data will be entered into a ground-water data base. Existing 1-foot contour topographic maps and other appropriate data will be digitized and entered into a GIS data base. A preliminary ground-water flow model of the Warwick aquifer will be developed with existing data to evaluate initial assumptions about the aquifer flow system and indicate where additional data need to be collected. 
Fieldwork will include relating all surface-water and ground-water reference marks and measuring points to a common datum using global positioning and making periodic surfacewater, ground-water, and water-quality measurements. Test drilling will be done and observation wells will be installed to better define the extent and thickness of the Warwick aquifer and to evaluate the Warwick aquifer's connection to the Spiritwood aquifer. Studies to determine and quantify the evapotranspiration processes that are important to the Warwick aquifer water budget, to determine the mechanics of recharge/discharge, and to quantify recharge/discharge will begin by installing three rain gages and conducting two low-flow studies on the Sheyenne River.

\section{REPORT PRODUCTS:}

Ground-water flow model of Warwick aquifer on Fort Totten Indian Reservation (planned).

Hydrologic basic data of Fort Totten Indian Reservation, North Dakota (planned).

Hydrology of Fort Totten Indian Reservation, North Dakota (planned). 


\section{DEVELOPMENT AND APPLICATION OF GEOGRAPHIC INFORMATION SYSTEM (GIS) DATA BASES FOR NORTH DAKOTA}

PROJECT NUMBER: ND 92-166.

LOCATION: Statewide.

PERIOD OF PROJECT: September 1992 to September 1994.

PROJECT CHIEF: Thomas B. Reed.

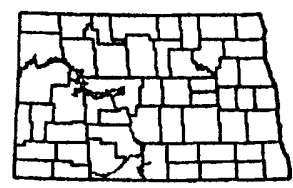

STATEWIDE

COOPERATING AGENCIES: (1) North Dakota State Department of Health and Consolidated Laboratories, and (2) North Dakota Geological Survey.

PROBLEM: Digital data bases and computer technology that allows rapid manipulation of large spatial data sets have become important tools for scientific analysis and as a means to produce illustrations for geologic and hydrologic investigations. Comprehensive spatial information on the geology and hydrology of North Dakota has been developed by various projects in recent decades. This information needs to be developed into GIS data bases.

OBJECTIVES: The purpose of this program is to help develop GIS data bases for North Dakota and to explore the potential uses of these data bases as an illustrative and analytical tool. Objectives are to (1) assess GIS data needs for those State and Federal agencies that deal with environmental and natural resource issues within North Dakota; (2) compile existing GIS data and develop additional data, such as boundary and public land survey coverages, as needed to produce a framework for a statewide GIS data base; (3) develop location algorithms for translating legal description locations into map coordinates; (4) develop procedures to acquire locational information produced by GPS techniques and integrate this information into the GIS data base; (5) produce integrated statewide GIS data bases, such as surficial geology and aquifer yield; (6) provide expert assistance in using GIS data bases to produce useful scientific information in digital or paper form for scientific illustrations; and (7) arrange demonstration projects to illustrate GIS technology and disseminate knowledge regarding this technology within North Dakota.

APPROACH: All U.S. Geological Survey National Mapping Division and other public domain data relevant to the framework of a statewide GIS data base will be compiled in the most readily usable format. GPS technology can provide an important source of positional data that can be integrated into a GIS data base. A plan will be developed and implemented to establish and maintain a community GPS base-station facility. A GIS data base for point data will be developed using existing data bases. Procedures for scanning paper maps and transferring them into vectorized GIS data sets will be developed. Grand Forks County will serve as a demonstration project for GIS techniques. Existing data from the county ground-water report will be input into a GIS data base. The geologic map and glacial aquifer yield map from the county ground-water report and other sources of readily available information will be input into GIS coverages.

PROGRESS: Digital data were acquired from the National Mapping Division for public land surveys and political boundaries (1:24,000) and hydrology and transportation (1:100,000). Geologic maps and glacial aquifer yield maps for Grand Forks County have been digitized from county ground-water reports.

PLANS FOR FISCAL YEAR 1993: Plans are to compile existing GIS data and develop additional data as needed to produce a framework for a statewide GIS data base. 


\section{DATA DEVELOPMENT AND ANALYSIS FOR USE IN GARRISON DIVERSION UNIT MONTHLY OPERATIONS MODEL ON THE JAMES RIVER}

PROJECT NUMBER: ND 92-167.

LOCATION: James River, North Dakota and South Dakota.

PERIOD OF PROJECT: September 1992 to September 1993.

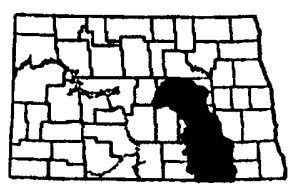

PROJECT CHIEF: Douglas G. Emerson.

COOPERATING AGENCIES: U.S. Department of the Interior, Bureau of Reclamation.

PROBLEM: The James River planning model developed by the U.S. Bureau of Reclamation requires, as input data, the unregulated and regulated streamflow at 13 gaging stations on the James River. Since the model was initially developed and applied, two additional gaging stations have been installed on the James River. Streamflow data of different record lengths are available for the 15 gaging stations along the James River in North Dakota and South Dakota. Data for 1953-82 were developed in a previous study. Data for 1983-91 now are required by the U.S. Bureau of Reclamation.

OBJECTIVES: Objectives are to (1) compile and extend the streamflow record, where necessary, to develop monthly streamflows at 15 gaging stations on the James River for 1983-91 and (2) estimate monthly unregulated streamflows for 1983-91 by using water-balance and statistical techniques for all 15 gaging stations.

APPROACH: Record extension can be accomplished by several techniques, including drainage-area ratio, regional statistics, regression, and precipitation-runoff modeling. In most cases, hydrologic judgment is used to select the best extension techniques. In the previous study, drainage-area ratio and regression techniques were used to extend streamflow records. For this study, the same techniques will be used for the record extension of each of the 15 gaging stations.

PROGRESS: None. New project.

PLANS FOR FISCAL YEAR 1993: Streamflow records for 1983-91 will be compiled and extended for the 15 gaging stations on the James River. The unregulated streamflow for 1983-91 for all 15 gaging stations will be computed. The report will be written and processed through review for Director's approval.

REPORT PRODUCTS:

Streamflow record extension for 15 gaging stations on the James River, North Dakota (planned). 


\section{OTHER ACTIVITIES OF THE NORTH DAKOTA DISTRICT}

To provide the hydrologic information and understanding needed for the optimum utilization and management of the Nation's water resources, the U.S. Geological Survey, Water Resources Division, is involved in numerous activities other than its regular programs of data collection and hydrologic investigations. Representatives of the U.S. Geological Survey serve on advisory committees, task forces, and ad hoc groups set up for specific purposes. Members of the North Dakota District staff participate in meetings, provide administrative support, and furnish information requested by various committees and task forces. Included are the North Dakota Nonpoint Source Water Quality Task Force, the Red River Water Resources Council, the Yellowstone River Compact Commission, the International Souris River Board of Control, the Souris River Bilateral Water-Quality Monitoring Group and its task forces, and the International SourisRed River Engineering Board.

District staff review Environmental Impact Statements for selected Federal projects to insure that available hydrologic data are used, that the data are used correctly, and that the impact of proposed developments on water features and resources is accurately evaluated. From time to time, the District also is asked to review reports and projects of other Federal agencies, primarily because of the Survey's hydrologic expertise and impartiality. District personnel occasionally are called upon to provide expert testimony concerning hydrologic information gathered or developed by the District that is relevant to a water-resources issue under litigation.

In addition to the U.S. Geological Survey's formal programs and studies, water information and assistance are provided to other agencies with specific problems. The District continually receives calls, visits, and mail requests for information on ground-water availability and water levels, streamflow magnitudes, water quality, and water use from scientists with other agencies, landowners, consultants, public officials, and business concerns. 


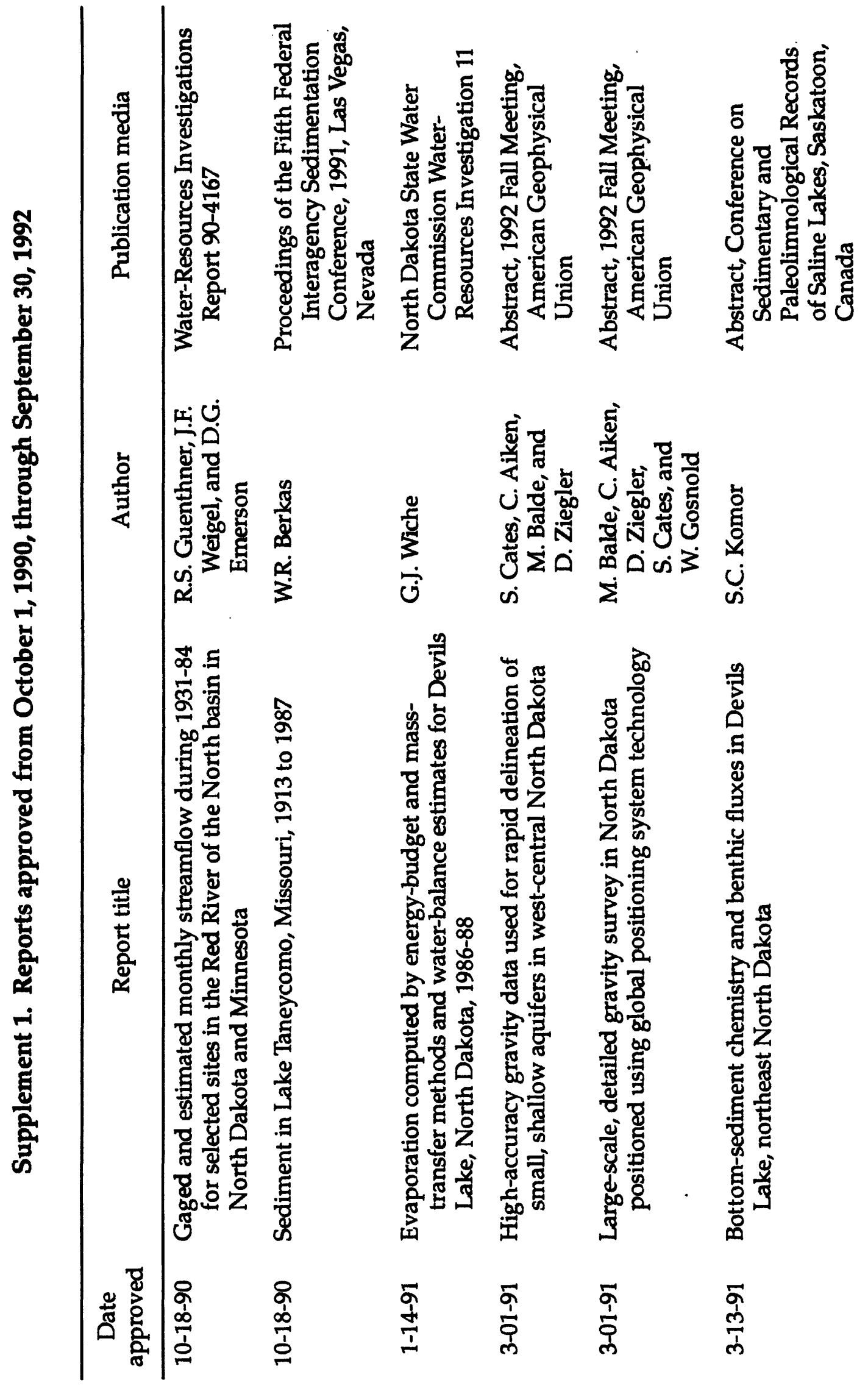




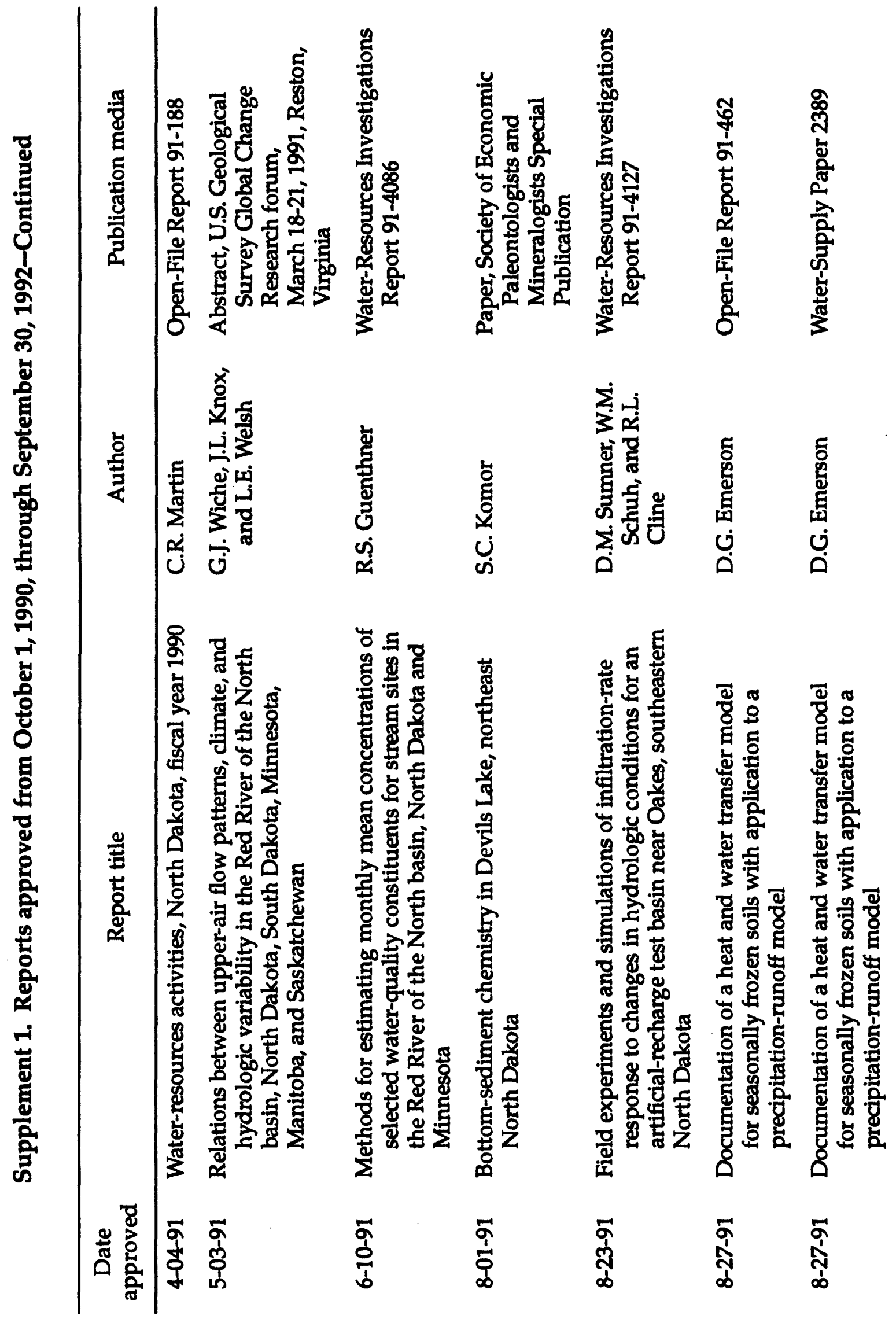




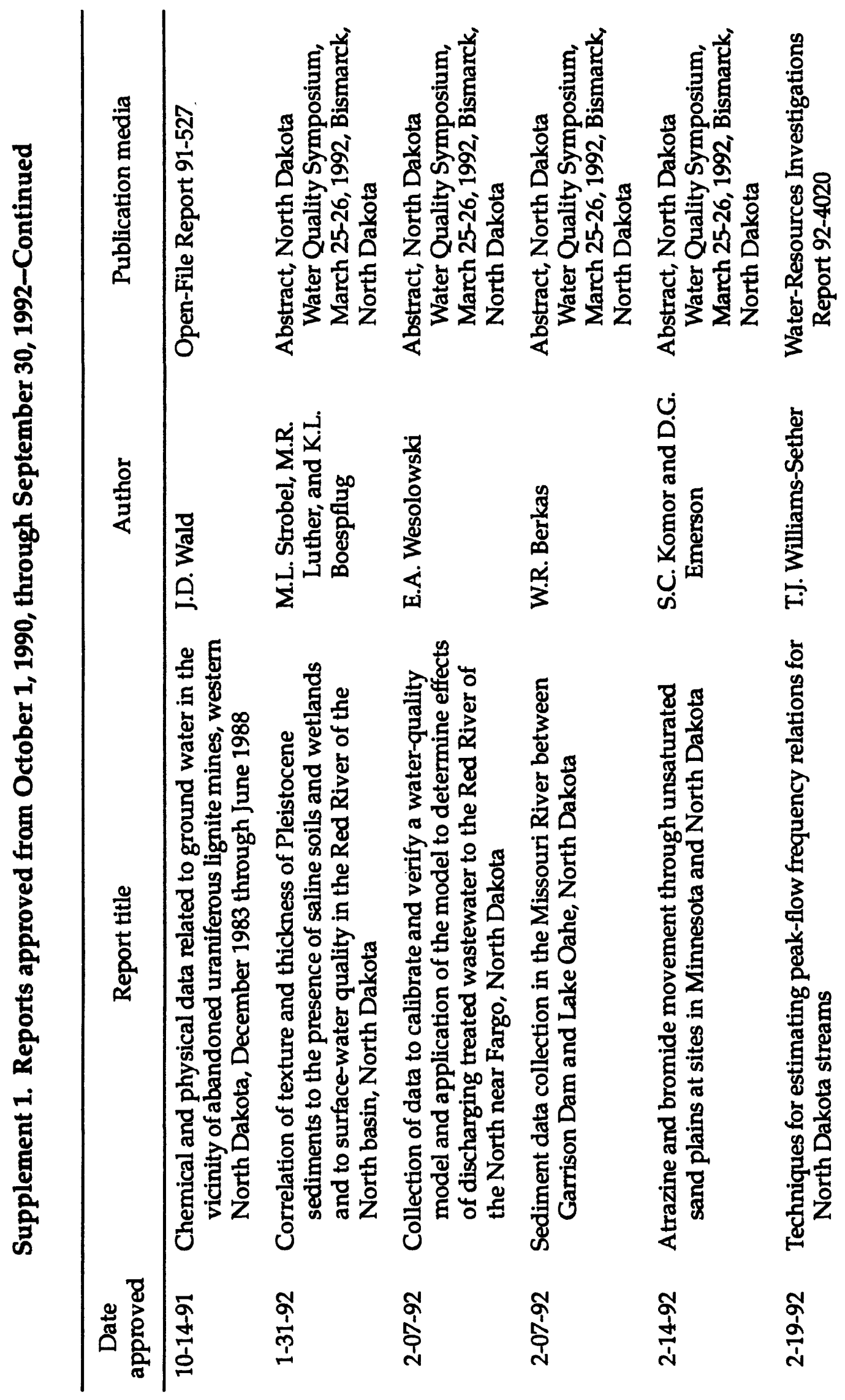




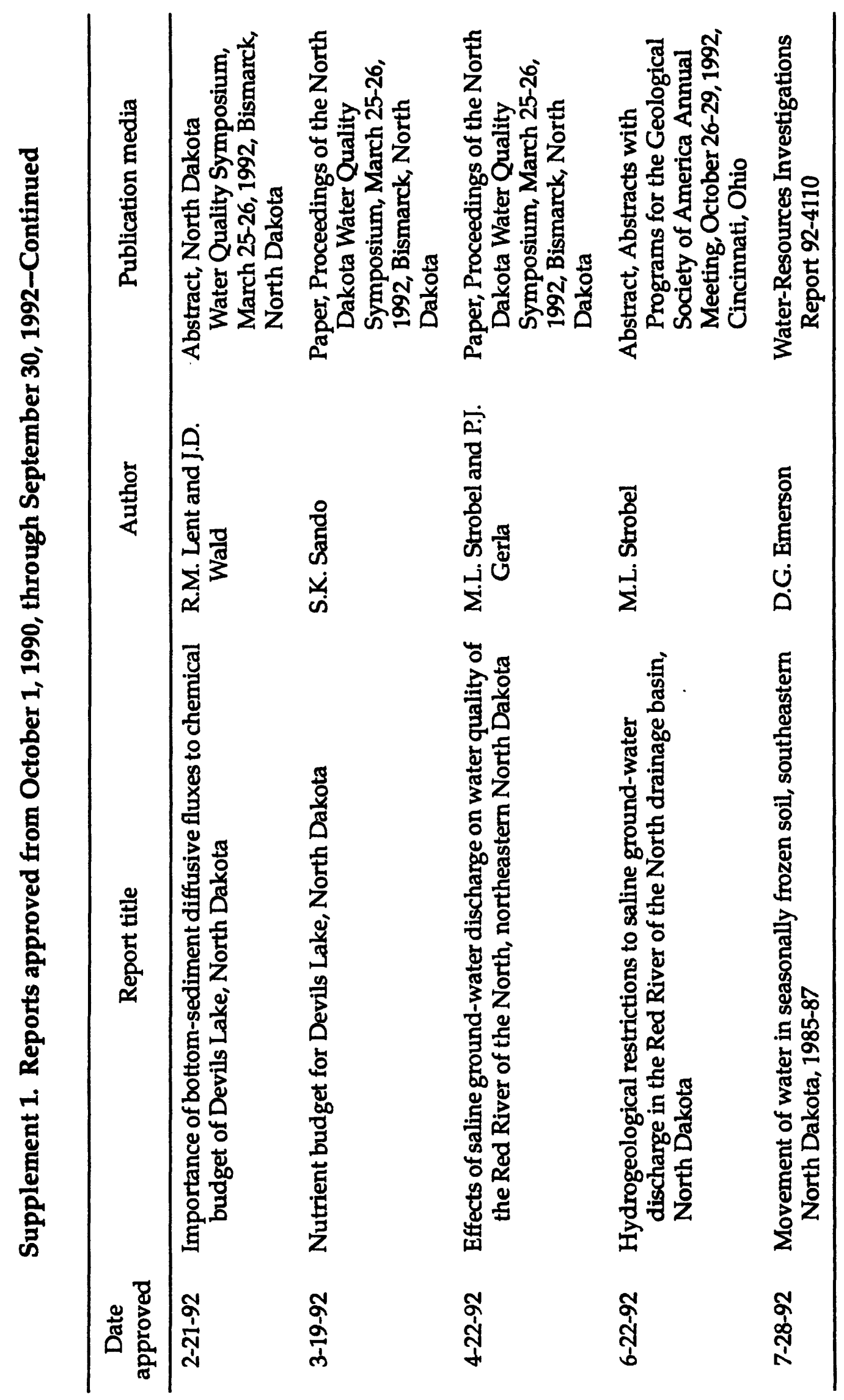

